\title{
Acoustic and petrophysical properties of mechanically compacted overconsolidated sands: Part 1 - Experimental results
}

\author{
Sirikarn Narongsirikul ${ }^{1,3}$, Nazmul Haque Mondol ${ }^{1,2}$, and Jens Jahren ${ }^{1}$ \\ ${ }^{1}$ University of Oslo \\ ${ }^{2}$ Norwegian Geotechnical Institute (NGI) \\ ${ }^{3}$ ConocoPhillips Norway
}

Contact Author: Sirikarn Narongsirikul

Affiliations: University of Oslo and ConocoPhillips Norway

E-mail: sirikarn_nar@hotmail.com

\section{KEYWORDS}

Acoustic, porosity, rock physics, overconsolidated sands, experimental compaction, uplift

\begin{abstract}
This paper part one is set out to lay primary observations of experimental compaction measurements to form the basis for rock physics modelling in paper part two. P- and S-wave velocities and corresponding petrophysical (porosity and density) properties of seven unconsolidated natural sands with different mineralogical compositions and textures are reported. The samples were compacted in a uniaxial strain configuration from 0.5 up to 30 MPa effective stresses. Each sand sample was subjected to three loading cycles to study the
\end{abstract}

This article has been accepted for publication and undergone full peer review but has not been through the copyediting, typesetting, pagination and proofreading process, which may lead to differences between this version and the Version of Record. Please cite this article as doi: $\underline{10.1111 / 1365-2478.12744 .}$.

This article is protected by copyright. All rights reserved. 
influence of stress reduction on acoustic velocities and rock physical properties with the key focus on simulating a complex burial history with periods of uplift. Results show significant differences in rock physical properties between normal compaction and overconsolidation (unloaded and reloaded). The differences observed for total porosity, density, and P- and Swave velocities are attributed to irrecoverable permanent deformation. Microtextural differences affect petrophysical, acoustic, elastic and mechanical properties, mostly during normal consolidation but are less significant during unloading and reloading. Different preconsolidation stress magnitudes, stress conditions (isotropic or uniaxial) and mineral compositions do not significantly affect the change in porosity and velocities during unloading as a similar steep velocity-porosity gradient is observed. The magnitude of change in the total porosity is low compared to the associated change in P- and S-wave velocities during stress release. This can be explained by the different sensitivity of the porosity and acoustic properties (velocities) to the change in stress. Stress reduction during unloading yields maximum changes in the total porosity, $\mathrm{P}$ - and $\mathrm{S}$-wave velocities of $5 \%, 25 \%$, and $50 \%$, respectively. These proportions constitute the basis for the following empirical (approximation) correlations: $\Delta \phi \sim \pm 5 \Delta \mathrm{V}_{\mathrm{P}}$ and $\Delta \mathrm{V}_{\mathrm{P}} \sim \pm 2 \Delta \mathrm{V}_{\mathrm{S}}$. The patterns observed in the experiments are similar to well log data from the Barents Sea. Applications to rock physics modelling and reservoir monitoring are reported in a companion paper.

\section{INTRODUCTION}

Compaction induces changes in acoustic and petrophysical properties of sediments and sedimentary rocks in subsiding sedimentary basins. Increase the vertical stress results in porosity loss and increase in the velocity. At shallow burial depths down to $\sim 2 \mathrm{~km}$, the compaction process is mainly mechanical (Bjørlykke 2010) and the changes in rock 
properties depend directly on stress and rock microstructure (i.e. mineralogy, grain size, and sorting). When siliciclastic sediments are buried deeper than $\sim 2-2.5 \mathrm{~km}$ (Bjørlykke and Egeberg 1993) and subsurface temperatures exceed about $70^{\circ} \mathrm{C}$, chemical compaction processes are triggered (Bjørlykke 1999). This results in increasing rock stiffness through mechanisms such as quartz cementation diagenesis.

Most laboratory mechanical compaction studies acquiring acoustic and petrophysical measurements reported in the literature employ normal loading stress paths, where the stress increment applied to the samples mimics normal progressive burial, e.g. in sands or sandstones (Yin 1992; Tao et al. 1995; Dvorkin and Nur 1996; Chuhan et al. 2003; Pettersen 2007; Mondol et al. 2010; Fawad et al. 2011; Grande et al. 2011; Bhuiyan et al. 2013), and in different clays, mudstones, and shales (Jones and Wang 1981; Goulty 1998; Hornby 1998; Wang 2002a, 2002b; Mondol et al. 2007; Dewhurst et al. 2011, Sarout et al. 2014, 2017).

In many sedimentary basins, however, the sediments have not only experienced simple progressive burial. More complex burial histories, like those found in uplifted basins, are also common. Table 1 lists several petroleum producing basins that have experienced uplift. Improving the understanding of the relationships between acoustic and petrophysical properties of stress-unloaded rocks in such basins is therefore desirable. The emphasis becomes more apparent considering that recent exploration and development of petroleum provinces are moving north into the Arctic region which is known to have been additionally affected by deglaciation rebound.

Unloading caused by uplift and erosion has significant impact on reservoir quality, hydrocarbon generation in source rocks, and seal integrity (Riis and Fjeldskaar, 1992). The resulting complex burial histories can influence the acoustic, petrophysical and mechanical properties differently compared to simple progressively buried sediments. This is seen on 
well logs where velocity and density of uplifted sediments are anomalously higher compared to normally compacted sediments at the given depth due to the preconsolidation (Narongsirikul et al. 2013a). In such cases, normal loading using conventional triaxial testing procedures will not appropriately describe the behaviour of decompacted rocks. Although many laboratory compaction experiments involve records of unloading steps these records are usually obtained when the sample is unloaded before being dismounted. These unloading data are generally not analysed in detail in terms of overconsolidation and uplifting. In addition, in the past few years, several experimental approaches have been developed with the aim of understanding the effects of complex burial histories or stress paths on rock properties, e.g. using rock physics modelling (e.g. Grude et al. 2013; Narongsirikul et al. 2013a, 2013b, 2013c; Draege et al. 2014; Avseth et al. 2016) and experimental compaction studies (Nygård et al. 2004; Grande et al. 2011). However, the understanding of the impact of stress unloading on rocks is still immature. More experiments designed to replicate complex burial and uplift histories can lead to improvements in the interpretation of subsurface data and the characterisation of unloaded rocks.

This study reports an experimental investigation of seven brine-saturated unconsolidated sands with varying mineralogical compositions and textures. The study applies complex stress paths under zero horizontal strain condition $\left(\mathrm{K}_{0}\right)$ including three stages of loading, partial unloading and reloading to simulate sediments that underwent several uplift-erosion episodes. The measurements reported here include: porosity and ultrasonic P- and S-wave wave velocities. Relationship between porosity and velocities were assessed. Quantification of changes in the measured parameters after stress reduction was also included to study the effect of preconsolidation. The results are compared with previously published sand compaction datasets and with well logs from the Barents Sea Shelf. The use of these 
laboratory data to build on existing rock physics models, and their applications to reservoir monitoring are reported in a companion paper (Narongsirikul et al. 2018).

\section{EXPERIMENTAL PROCEDURE}

An axi-symmetric triaxial cell located at the Norwegian Geotechnical Institute (NGI) was used for measurements of rock properties in this study. The detailed setup of the triaxial cell is described in detail in Berre (2011, Figure 1). The configuration of the triaxial apparatus allows measurement of vertical and horizontal P- and S-wave velocities. The P- and S-wave velocities were measured using the pulse transmission technique (Birch 1960). The vertical P- and S-wave transducers, for wave propagation in the direction parallel to the vertical load, along the axis of cylindrical sample are mounted inside the top and bottom platens attached to the rock sample, allowing arrival times of the transmitted waves to be recorded (Figure 1).

The samples were initially isotropically compacted to an effective stress of $0.52 \mathrm{MPa}$ in the triaxial cell. The effective stress was then increased from 0.52 to $30 \mathrm{MPa}$ under a uniaxial strain condition $\left(\mathrm{K}_{0}\right)$, which was maintained through adjustment of radial stress $\left(\sigma^{\prime} \mathrm{h}\right.$, onset, Figure 2). Pore pressure was kept constant at $1 \mathrm{MPa}$ throughout the experiments. At 15, 25, and $30 \mathrm{MPa}$ effective stresses partial unloading was carried out by decreasing the vertical load followed by reloading to the next stress level (Figure 2). Step-by-step loading procedures are shown in Table 2. The loading, unloading, and reloading rates were kept constant at $3.75 \mathrm{MPa} / \mathrm{hr}$. Creep was allowed for all samples but the time allowed for creep varies among samples. The maximum experimental error for the applied vertical effective stress and pore pressure is $\pm 0.005 \mathrm{MPa}$ or $\pm 0.5 \%$ and for displacement is $\pm 0.0001 \mathrm{~mm}$ or for strain is $0.01 \%$. The uncertainty in P-wave velocity measurements is $1 \pm 0.2 \%$ and in S- 
wave velocity measurements is $3 \pm 0.5 \%$. Details of velocity error calculations are contained in Mondol et al. (2008).

A maximum strain amplitude of the order of $10^{-2}$ can be achieved in this experimental setup. The strains were continuously recorded during each loading cycle through the changes in the sample height and diameter using vertical and horizontal deformation sensors (Figure 1). Wave velocities were estimated approximately every $5 \mathrm{MPa}$ effective stress. The velocities were calculated from absolute sample height at different target stress levels divided by the wave travel time through the samples. The travel time used in the calculation for both P- and S- waves $\left(\Delta \mathrm{t}_{\mathrm{P}}\right.$ and $\left.\Delta \mathrm{t}_{\mathrm{S}}\right)$ is the difference between reference signals measured with no samples (head to head source/receiver configuration) and with coupled samples (Figure 3). The first breaks of the S-wave velocity at very low stress levels (i.e. below $5 \mathrm{MPa}$ in most samples and at $10 \mathrm{MPa}$ in some samples) are not reliably detected as these waves are highly attenuated. Hence, extrapolation of the data is required using appropriate relationship for each sample to predict the missing S-wave velocities.

\section{SAMPLE DESCRIPTION AND PREPARATION}

\subsection{Sample description}

A total of seven experimental compaction tests were performed on seven brine-saturated natural sand aggregates. The sand samples were collected from different locations on several beaches in Norway and Denmark. The sands are different both in mineralogical compositions and textures. Quantitative X-Ray Diffraction (XRD) data for these sands were reported by Fawad et al. (2011). This leads to a classification of the samples into the following sand types: Quartz Arenite (QA), Arkosic Arenite (AA), Subarkose (SA), Feldspathic Greywacke (FG) and Volcanic Arenite (VA), following Dott's sandstone classification (1964). Based on 
the XRD results, the sand samples are quartz dominated with 35 to $98 \%$ quartz by weight, except for the Volcanic Arenite sample which contains only 5\% quartz. Other constituents include feldspars, clays, and other minerals (Table 3).

The textural variations of these sands can be described in terms of grain size, grain shape, and sorting. Previous studies have shown that textural variations of sands can influence seismic and physical properties considerably (Fawad et al. 2011). Among different textural parameters, sorting has been shown to most influence seismic and petrophysical properties of granular sands through non-contact pore filling materials (Dvorkin and Nur 1996; Fawad et al. 2011). The effect of other less influential textural parameters is not a focus in this study. The sorting of the sands was classified using standard deviation of the grain size weight percentage determined by sieve analysis (Table 4). The conventional sieving method was employed to separate the sand samples into size fractions ranging from very coarse sand $(>1000 \mu \mathrm{m})$ to silt $(<63 \mu \mathrm{m})$. The degree of sorting (phi) was computed using standard deviation of the separated grain size weight percentage (Table 4). Figure 4 shows example photographs of QA1 sample from sieving analysis in different grain sizes ranging from $>1000$ microns (Very Coarse) to $<63$ microns (Silt). More details of the samples for mineral compositions and full textural descriptions can be found in Fawad et al. (2011).

It is worth noting that all samples were compacted using the loading procedures previously described in the experimental procedure section, except for the Volcanic Arenite (VA) sample. The data for this sample were taken from Grande et al. (2011) in which the unloading/reloading cycles were applied at an effective stress of 10, 20, and $30 \mathrm{MPa}$ instead of 15,25 , and $30 \mathrm{MPa}$ for the other samples. 


\subsection{Sample preparation}

The sand samples were prepared in a loose state inside a rubber sleeve placed within a stiff removable cylinder with dimensions of $38 \mathrm{~mm}$ in diameter and $60 \mathrm{~mm}$ in height. The sand samples were packed in thin layers using the under-compaction method described by Ladd (1978) to achieve a homogenous state and loose packing. Thus, the solid frame of the sand samples can be assumed homogenous at the sample scale and isotropic in the pre-stressed condition. To assure complete saturation prior to compaction, vacuum was applied before fluid saturation to ensure no air was left inside the samples. Carbon dioxide $\left(\mathrm{CO}_{2}\right)$ was then applied and left within the samples for a few minutes before brine solution $(35 \mathrm{~g} \mathrm{NaCl}$ per litre of water) was injected into the samples. Lastly, we introduced the back pressure application to ensure fully liquid saturation. Details of the back pressure application can be found in Berre (2011)

The initial porosity calculation was based on a gravimetric analysis where mass, volume and grain density of the samples were measured. The measured parameters were then used to calculate the porosity using the following equation:

$$
\phi_{i}=\frac{\mathrm{V}_{i}-\left(m_{s} / \rho_{s}\right)}{V_{i}}
$$

where $\varphi_{\mathrm{i}}$ is the initial porosity in fraction, $\mathrm{V}_{\mathrm{i}}$ is the bulk volume of the sample computed from the initial sample height and the sample diameter at room conditions. The $\mathrm{m}_{\mathrm{s}}$ and $\rho_{\mathrm{s}}$ is the mass and grain density of the grain constituents in the sample which were determined with a pycnometer (Table 3$)$.

The initial bulk density was computed from the mass of sand, brine and sample volume using the following equation: 


$$
\rho_{b}=\frac{m_{s}+\left(\mathrm{V}_{i} \phi \rho_{f}\right)}{\mathrm{V}_{i}}
$$

Equation (4) can be re-arranged in the following form:

$$
\rho_{b}=(1-\phi) \rho_{s}+\phi \rho_{f}
$$

where $\rho_{\mathrm{b}}$ is the bulk density, $\varphi$ is the total porosity, and $\rho_{\mathrm{f}}$ is the density of $\mathrm{NaCl}$ solution $(1.02 \mathrm{~g} / \mathrm{cm} 3)$. The porosity and density changes at different effective stresses were then calculated using the same equations (3) to (5), while the sample volume $\mathrm{V}_{\mathrm{i}}$ was monitored using the measured changes in sample height and diameter as a function of effective stress.

\section{EXPERIMENTAL RESULTS}

\subsection{Effect of mineralogy and sorting}

Results of the experimental compaction of all samples combining normal loading, unloading, and reloading cycles in terms of total porosity, density, P-wave velocity, and S-wave velocity, with each attribute plotted versus effective stress, are shown in Figure 5. Note that throughout the rest of the paper, the term porosity denotes the total porosity of the samples. The effect of both mineralogy and sorting on acoustic and petrophysical properties were demonstrated by colour coding the symbol with quartz content (left graphs), and with sorting (right graphs). Quartz content and sorting are separated into three groups each. For the mineralogy, the samples were grouped into 80 to $100 \%$, 40 to $80 \%$, and 0 to $40 \%$ quartz content. For sorting, the samples were grouped into poorly sorted (sorting degree (phi) is $>=1.00$ ), moderately sorted (phi ranges between $0.75-0.99$ ), and well sorted (phi ranges between $0.50-0.74$ ) based on the sample classification from Table 4 (Figure 5, right graphs). The results show that at any given effective stress the porosity generally is high in the samples with high quartz percentage. Throughout the rest of the paper, high quartz content 
represents the samples comprised of low amount of either ductile and clay minerals or both. In contrast, the samples with low quartz contain higher amount of ductile and/or clay minerals. A similar behavior is expected in the $\mathrm{P}$ - and S-wave velocities where the group of samples with high quartz content exhibits lower velocities compared to the group of samples with low quartz content. Sorting shows a significant effect on the porosity where the well sorted group members (colour coded in red) have the highest porosity value compared to the other two group members. Sorting effects are less clear for bulk density and P- and S- wave velocities. This can be attributed to other textural effects such as grain shape, grain size, and high grain density comprised in some samples (i.e. VA) which are not considered in the present study.

Note on all plots in Figure 5 that the dataset are very scatter and difficult to interpret as all measured data points at all stress levels were included. Figure 6 shows the same data but separately plotted only normal loading on the first and the third columns (circles) and the last unloading on the second and the fourth columns (squares) of all sand samples. This is in order to remove scatter of the data to allow for better interpretation. The density was also excluded from Figure 5 as both bulk density and porosity are directly proportional to each other.

By separating unloading from the normal loading on Figure 6, it becomes clear that during normal loading, P-wave and S-wave velocities and porosity are notably affected by the microtextures. This is shown by multiple velocity-stress and porosity-stress trends that link the data at low effective stress level to the highest stress level at $30 \mathrm{MPa}$ on the first and the third columns in Figure 6. The velocity-stress trends of the last unloading for both P-wave (the second and the fourth columns on row two) and S-wave velocities (second and fourth columns on row three) are similar to the normal loading trends. However, the porosity 
behaviors of the unloading data are less affected by mineralogy and sorting. This is shown on the second and the fourth columns on row one that only a similar and steep porosity-stress trend was observed for all unloaded samples.

\subsection{Effect of stress path and preconsolidation stress on velocity and porosity}

The effect of stress path and preconsolidation stress were assessed on the plots on Figure 7. Only two representative samples of the two end members, Quartz Arenite 2 (highest quartz content, 97.88\%, left column) and Feldspathic Greywacke (lowest quartz content, 35.5\%, right column) were chosen to allow clarity of the data. The data for both normal loading and three unloading/reloading cycles were included. Note that Volcanic Arenite that was tested in Grande et al. (2011) has the lowest quartz content of $4.84 \%$ which could have represented the low quartz end member. However, the loading path is different from the rest of the samples. Therefore, Feldspathic Greywacke was selected to represent the low quartz end member instead.

Both samples deform considerably during the application of stress increments. Total porosity loss, and P- and S- wave velocities for both samples increase with increasing effective stress during normal consolidation (black curve with open circle symbols), and decrease with decreasing effective stress during unloading (blue, green, and red curves with square symbols). However, the velocity-stress and porosity-stress relations of the samples subjected to overconsolidation (unloading and reloading) show hysteresis. The separation between the overconsolidated and the normally consolidated trends are more pronounced for the total porosity compared to the velocities. This shows that porosity has higher hysteresis compared to velocities as stress was released. 
The hysteresis of porosity can be explained quantitatively in the porosity-stress plot, see Quartz Arenite 2 as example (Figure 7, top left). The initial porosity of the sample is approximately $43 \%$. The continuous deformation resulting in the loss of porosity occurs simultaneously with increasing effective stress. At $30 \mathrm{MPa}$ when the stress reaches its maximum target level, the total porosity decreases to $35 \%$, that is a reduction by 8 units compared to the unstressed state. The porosity continues to decrease slightly at constant 30 MPa effective stress. This shows that creep has an effect on the rock properties, both velocities and porosity. The porosity in the course of overconsolidation only increases slightly to $36 \%$ as the stress was removed. The degree of porosity change during unloading/reloading (from $35 \%$ increased to $36 \%$ ) differs greatly compared to the change during the normal consolidation (from $43 \%$ reduced to $35 \%$ ). The minor porosity change associated with stress release during unloading and reloading shows that porosity becomes less stress sensitive after preconsolidation.

The effects of preconsolidation stress on P- and S-wave velocities and porosity can also be observed on the same figure (Figure 7). The P- and S- wave velocities and porosity of the overconsolidation (unloading, squares) deviate systematically from the normal compaction (loading, circles) trends at any given effective stress for both FG and QA2 samples. The degree of deviation depends on the magnitude of the maximum pre-compaction stress that the samples have experienced. Direction of increasing maximum preconsolidation stress prior to each unloading was marked in red arrow in all plots.

\subsection{Velocity and porosity relations}

Figure 8 shows $\mathrm{P}$ - and S-wave velocities versus total porosity using the two representative end members Quartz Arenite 2 (QA2) and Feldspathic Greywacke (FG). The data are colour coded based on effective stress at the time of the data recording. Both P- and S- wave 
velocities versus total porosity plots show an increase in velocities and a decrease in porosity with increasing effective stress. During stress release from different preconsolidation stress levels $(15,25$, and $30 \mathrm{MPa})$, there is a much steeper velocity-porosity gradient compared to the velocity-porosity trends found during normal compaction. The trends recorded during stress release are found to be parallel to each other. The data also show that varying preconsolidation stress levels do not significantly impact the velocity - total porosity coefficient denoted by the gradient of the velocity-total porosity curve during stress unloading in overconsolidated sands.

\subsection{Quantification of change in velocity and porosity during unloading}

Changes in velocity and porosity of the sands during unloading/reloading can give quantitative estimation on the magnitude of deviation of the rock properties from the previous loaded stage. The estimation could be used to predict rock properties in basin analysis of sediments in uplifted regions and also during petroleum production to understand the change in reservoir compaction due to depletion and re-pressurization.

Figure 9 shows the changes in P- and S-wave velocities and total porosity of all sands, except VA sample, in three unloading/reloading cycles. The estimated changes are the difference between the considered parameters at a current given stress and the past maximum stresses relative to the parameters at the maximum stresses, which are expressed as:

For the change in P-wave velocity (\%):

$$
\Delta V_{P}=\frac{V_{P \max }-\mathrm{V}_{P}}{\mathrm{~V}_{P \max }} * 100
$$

For the change in S-wave velocity (\%):

$$
\Delta V_{S}=\frac{V_{S \max }-\mathrm{V}_{S}}{\mathrm{~V}_{S \max }} * 100
$$


For the change in total porosity $(\%)$ :

$$
\Delta \phi=\frac{\phi_{\max }-\phi}{\phi_{\max }} * 100
$$

For the change in effective stress (\%):

$$
\Delta \sigma_{V}^{\prime}=\frac{\sigma_{V}^{\prime} \max -\sigma_{V}^{\prime}}{\sigma_{V}^{\prime} \max } * 100
$$

The $\mathrm{V}_{\mathrm{P} \max }, \mathrm{V}_{\mathrm{S} \max }$, and $\phi_{\max }$ are the values at the maximum stress $\left(\sigma^{\prime}{ }_{\mathrm{V} \max }\right)$ from three loading cycles prior to unloading. The $\mathrm{V}_{\mathrm{P}}, \mathrm{V}_{\mathrm{S}}$, and $\phi$ are the values at any given stress $\left(\sigma^{\prime}{ }_{\mathrm{V}}\right)$ during unloading and reloading.

For all the plots in Figure 9, different symbols denote different samples. The symbols colour coded in blue, green and red correspond to the $1^{\text {st }}, 2^{\text {nd }}$, and $3^{\text {rd }}$ unloading /reloading cycles when the sample experiences maximum preconsolidation stress of 15,25 , and $30 \mathrm{MPa}$, respectively. All parameters $\left(\Delta \mathrm{V}_{\mathrm{P}}, \Delta \mathrm{V}_{\mathrm{S}}\right.$, and $\left.\Delta \phi\right)$ were plotted as functions of the change in the effective stress $\left(\Delta \sigma^{\prime}\right.$ v). It was observed that all overconsolidated samples with different mineral compositions and textures have the same degree of change in velocities and porosity. Note that a positive change in velocity means the velocity decreases as a result of the unloading, whilst a negative change in the porosity means the porosity increases. The changes in all parameters exhibit $2^{\text {nd }}$ order non-linear polynomial functional relationships to the change in the effective stress, considering the entire stress range ( $0 \%$ to $100 \%$ change). A linear elastic trend can be observed for all parameters when the change in the effective stress is below $\sim 60 \%$ or $70 \%$ (Figure $9 \mathrm{a}-\mathrm{c}$ ). Beyond this point, the trends drastically deviate from linearity. This implies that when the release of stress exceeds a linear elastic yield point, the solid skeleton of the rock loosens and the number of grain contacts decreases.

In the same plots, the change in velocity for the entire stress change $(0 \%$ to $100 \%)$ is observed to be larger than the change in the total porosity. The S-wave velocity change is 
approximately a factor of 2 larger than the P-wave velocity change. The P-wave velocity change is approximately a factor of 5-6 larger than the change in porosity for any given stress change. For example, considered at 50\% stress change (50\% amount of stress reduced from the maximum preconsolidation stress, marked black arrows on the plots), the corresponding changes in porosity, $\mathrm{P}$-wave and $\mathrm{S}$-wave velocities are approximately $1 \pm 0.2 \%, 6 \pm 1 \%$, and $12 \pm 2 \%$, respectively. The total change in the porosity and $\mathrm{P}$ - and $\mathrm{S}$ - wave velocities approximately $5 \%, 25 \%$, and $50 \%$, respectively when the stress release is $100 \%$, which leads to the approximation of $\Delta \phi \sim \pm 5 \Delta \mathrm{V}_{\mathrm{P}}$ and $\Delta \mathrm{V}_{\mathrm{P}} \sim \pm 2 \Delta \mathrm{V}_{\mathrm{S}}$.

\section{DISCUSSION}

\subsection{Comparison of velocity-porosity relationship with previously published studies}

The studied dataset was compared to 18 brine-saturated sand compaction tests from four published experimental studies by Yin (1992), Zimmer (2003), Fawad et al. (2011), and Zadeh et al. (2016). The unloaded sand data are available only in Yin and Zimmer's dataset, whilst Fawad et al. and Zadeh et al. studies are available only normal consolidation. The samples from Fawad et al. (2011) are the same sand materials used in this study. The samples used by Zimmer (2003) are sand aggregates comprised of mainly quartz with subordinate amounts of plagioclase, K-feldspar and clays. The samples from Yin (1992) and Zadeh et al. (2016) contain predominantly quartz with small amount of kaolinite. Details of all samples taken from previous studies with brief sample descriptions and loading procedures are listed in Table 5.

The loading procedures used by Yin (1992) and Zimmer (2003) and similar to the loading procedure used in this study, where loading, unloading, and reloading cycles with increasing peak stress (50 and $20 \mathrm{MPa}$, respectively) applied to the samples. However, the stress 
condition set up for these two published datasets is different from this study, where isotropic stress condition is applied to their samples. Zimmer's samples also were fully unloaded back to the starting stress level at each cycle, instead of partially unloaded/reloaded like what was performed in our experiment. The additional four published datasets make it possible to compare acoustic velocity and porosity response for datasets with (1) similar loading procedures, which include unloading, but different mineral compositions (Yin 1992, and Zimmer 2003, data shown as blue and red respectively in Figure 10), (2) similar loading procedures but different stress conditions (isotropic stress condition applied by Yin 1992, and Zimmer 2003), and (3) the same composition but using different experimental setups (oedometer setup in Fawad et al. 2011, data shown as blue magenta in Figure 10). High quartz data from Zadeh et al. 2016 with the same loading procedures and experimental setup as Fawad et al. are also included.

All four published sand datasets and the present data are plotted on velocity versus porosity space in Figure 10. The plots were separately between normal loading (top graphs, circles) and unloading (bottom graph, squares). Only the last cycle of the unloading data is plotted for clarity.

All five datasets show velocities and porosities within approximately the same range. The overall porosity ranges between $24-44 \%$ and the $\mathrm{P}$ - and S-wave velocities range between 1.8 $-2.8 \mathrm{~km} / \mathrm{s}$ and $0.4-1.2 \mathrm{~km} / \mathrm{s}$, respectively. The initial porosity varies between $33-45 \%$ depending on sorting. All normally compacted sand datasets show the various velocityporosity trends (circles) attributed to the microtexural differences between the samples. However, unloading data only available from Yin and Zimmer show a single steep velocity versus porosity trend comparable to the results from the present study (grey squares). The effect is seen even though their mineral compositions, maximum preconsolidation stress, and 
stress condition (isotropic) differ from the present study. This confirms our earlier observation that microtextures, preconsolidation stress magnitudes, and stress conditions (isotropic or uniaxial) do not significantly influence the velocity-porosity gradient during stress reduction. This suggests that a single velocity-porosity coefficient may be approximated for any loose overconsolidated sand with varying compositions and preconsolidation stress magnitude which allows for a generalisation of a constitutive equation for porous materials in velocity, porosity and stress space.

A small difference between the normally consolidated dataset taken from Fawad et al. (2011, magenta circles) and the present study (grey circles) was observed, even though both compaction studies performed on the same samples. This may be explained by the differences in sample holder geometry. The samples used by Fawad et al. (2011) were tested in an oedometer which is wide and relatively short while the samples in this study were tested in a triaxial cell which is narrow and tall. The sample geometry influence on measurement results was reported by Bhuiyan et al. (2013) from the measurements on sands and clays in the triaxial and oedometer systems. In addition, the discrepancies may be explained by different boundary conditions and stress paths within the different sample holders. Steel was used in the oedometer, while a thin soft rubber sleeve was used in the triaxial system. Bhuiyan et al. (2013) also observed that the most significant sources of discrepancy between datasets obtained from different methods stems from the manufacturing and preparation of the samples. This latter explanation may be the most important for the minor velocity and porosity discrepancies observed between the two datasets.

\subsection{Mechanism governing velocity and porosity reversal during stress release}

Stress reduction due to unloading resulted in velocity and porosity reversal in velocityporosity, velocity-stress, and porosity - stress spaces for all samples. This result is expected in 
soil mechanics testing and is also reported in several other compaction studies where unloading has been taken into account (e.g., Yin 1992; Holt 1999; Zimmer et al. 2007; Gomez et al. 2010; Brzesowsky et al. 2014). The results show that the compaction is mostly inelastic and only a small elastic part of the deformation is reversed during unloading. The stress release causes fractional recovery of the deformed solid skeleton, and consequently velocities and porosity marginally change. In addition, the velocity has a greater recovery tendency during the stress unloading than the porosity.

When comparing the reversal behaviour between velocity and porosity, the velocities for both P- and S- waves show greater increases than porosity. The reason for this may be that the porosity/density known as bulk properties is sensitive only to the net pore volume of the rock (Bower 1995; Bower and Katsube, 2002). This is essentially different from wave velocity where wave propagation also depends on the geometry of the pores, how pores are interconnected and oriented with respect to the wave propagation path. Although Bower and Katsube (2002) concept is applied to shale microstructure, we find that this effect on acoustic properties is also applicable to sands.

\subsection{Quantification of velocity and porosity change during stress release compared to other studies}

The changes in velocity and porosity during stress release observed in this study as shown in Figure 9 are close to those reported by Holt (1994) during his experimental study of the effect of coring on porosity and acoustic velocity. Holt (1994) shows that for weak synthetic sandstone with initial porosity of $30 \%$, the effect of unloading causes a porosity increase of $1 \%$ absolute porosity and a velocity decrease of $30-50 \%$.

The result from section 5.1, when qualitatively comparing velocity - porosity relation, shows that Zimmer (2003) data show a behavior similar to the present study. In this section, a 
quantitative comparison between Zimmer data and the present study is performed. The change in velocity and porosity during stress release using equations 6-9 was estimated for Zimmer's wet Merrit sand sample. The preconsolidation stress from Zimmer's loading procedure varies with the maximum stress of 10, 15, and $20 \mathrm{MPa}$ prior to unloading (Figure 11). These are depicted in blue, green, and red, respectively. Zimmer's loading procedure applied more loading, unloading, and reloading cycles than the present study, with the preconsolidation stress range as small as $0.2 \mathrm{MPa}$ up $20 \mathrm{MPa}$. However, the calculation was only performed on the data with the preconsolidation stress at 10, 15, $20 \mathrm{MPa}$ as these are within the same maximum preconsolidation stress ranges applied in the present test. The estimation shows that the magnitude of deviation from the start of the release of stress $\left(\Delta \sigma^{\prime}{ }_{\mathrm{v}}\right.$ $=0 \%)$ to the highest degree of stress unloading $\left(\Delta \sigma^{\prime} \mathrm{v}=100 \%\right)$ accounts for a total of $6 \%$, $23 \%$, and $75 \%$ changes in porosity, and P- wave, S-wave velocities, respectively. The changes have a similar magnitude as observed in the present study for P-wave velocity and porosity; however S-wave velocity change in Zimmer's sample is higher. This may be attributed to both the higher magnitude of stress release and the isotropic loading/unloading applied to the Zimmer's sample compared to the uniaxial unloading in the present study. When considered the linear portion of data at the stress reduction up to $60-70 \%$, a closer match of all three parameters in Zimmer's to the present study is found. For example, at the $50 \%$ stress change, the quantitative changes in the porosity and P- and S-wave velocities are approximately $1 \%, 3-6 \%$, and $11-15 \%$, respectively (marked black arrows). The mismatch of the change in S-wave velocity from Zimmer's to the present study mostly occurs in the nonlinear portion, when the stress change is greater than $70 \%$. Note that although the maximum preconsolidation stress between Zimmer Merrit sands and our present dataset are different (20 MPa for Zimmer and $30 \mathrm{MPa}$ for present study), the change in P-wave velocity and total porosity between the two dataset is still within the same range. This confirms the earlier 
observation (e.g. Figure 10, section 5.1) that presonsolidation stresses and composition do not significantly affect the magnitude of change in velocity and porosity during stress-release.

\section{EXAMPLE FROM THE BARENTS SEA AREA}

In order to relate the experiments to a relevant geological setting, the experimental results were compared to well log information from the uplifted Barents Sea area (Riis and Fjeldskaar 1992; Faleide et al. 1996; Japsen and Chalmers 2000).

In order to relate the results from experimental study to the uplifted Barents Sea basin, several assumptions must be made:

(1) Pore pressure remains hydrostatic during burial, uplift/erosion, and reburial (drained);

(2) Rate of burial, uplift/erosion and reburial remains constant; and

(3) Principal effective stress direction is vertical.

(4) No chemical diagenesis takes place

Sonic and density log data from shallow sands affected by uplift/erosion from the Hammerfest Basin in the Barents Sea (well 7121/5-1) were used in the comparison with the experimental data. Any effects of temperature or creep on the log data were not considered in the comparison. This may result in some systematic differences in addition to those inherent between nature and laboratory analogue. As the experimental data herein are valid for preand post-uplift within the mechanical compaction domain, only the shallow sandy Cenozoic Nordland Group and Torsk Formation sequences were used in the comparison. To confirm whether the Torsk Formation in the studied wells had been within the mechanical compaction domain only past maximum burial depths were evaluated. Present base depth of the Torsk 
Formation sediments in the studied wells ranges between 450 and $780 \mathrm{~m}$ below sea floor (BSF). Below these depths, the formation comprises mainly clays and is not valid for comparison with the studied sand samples (Figure 12). The total amount of uplift based on Vitrinite Reflectance data (Ohm et al. 2008) range between 500 and $1000 \mathrm{~m}$. The maximum historical burial depth of the Torsk Formation sediments studied can therefore be estimated to be between about 1000 and $1700 \mathrm{~m} \mathrm{BSF}$. In basins with an average normal geothermal gradient $\left(35^{\circ} \mathrm{C} / \mathrm{km}\right)$, the transition from mechanical to chemical compaction takes place at around 2000-2500 m corresponding to $70-90^{\circ} \mathrm{C}$ (Bjørlykke and Egeberg 1993). Based on the maximum burial estimates of the studied Torsk Formation sediments above, these are well within the mechanical compaction domain.

In addition to the uplifted Torsk Formation sections from the Hammerfest basin, one Torsk Formation section from the Tromsø Basin (well 7117/9-1) was included in the comparison. This Tromsø Basin well has not been affected by Cenozoic uplift and represents normally compacted sediments. The base of the Torsk Formation in this well is at a present-day depth of around $1500 \mathrm{~m}$ BSF. This depth corresponds to the estimated past maximum Torsk Formation burial depths in the uplifted wells.

The P-wave velocity calculated from sonic transit time inversion and bulk density from the normally compacted sediments from the 7117/9-1 well (black squares) and the uplifted/overconsolidated sediments from 7121/5-1 (red squares) are plotted versus depth in Figure 12. A volume of clay (Vclay) of 0.2 was used to separate out the shallow sandstone intervals in the studied wells. A clear separation of both P-wave velocity and bulk density can be seen between an uplifted section of the Nordland Group and a normally compacted section of the same Nordland Group interval from the two selected wells observed at the same depth of interest. This deviation is qualitatively similar to the results observed in the experimental 
data (e.g. Figure 7). To compare the magnitude of the deviation between log derived velocity and bulk density data, we superimposed experimental data in the present study onto the same plot (Figure 12). Only the samples with high quartz content greater than $80 \%$ were selected to compare with the selected well logs with low $\mathrm{V}_{\text {clay }}$ with $20 \%$ cut-off. We find that the experimental curves of normally consolidated sand samples (black dashed curves) show overall better correlation with the well log data compared to overconsolidated for both Pwave velocity and bulk density. The overconsolidated (red dashed curves) condition on the other hands shows a reasonable fit for bulk density but a significant mis-match for the velocity. This could be explained by the difference in frequency between sonic and ultrasonic of four orders of magnitude. The poor correlation in the overconsolidated case can also be attributed to temperature, creep, and diagenesis of the burial history of the well logs data cannot be captured and fully implemented in the experiments.

Any velocity deviation from normal mechanical compaction trends can in general be an indication of cementation (Avseth et al. 2005), uplift and erosion (Al-Chalabi and Rosenkranz 2002), or over pressure and the presence of gas (Prasad 2002). The results herein confirm the higher seismic velocities in uplifted sediments compared to normally compacted sediments found at the same depth.

\section{CONCLUSION}

Experimental mechanical compaction of sands integrating loading, unloading and reloading cycles confirms that stress release affects the rock physical properties and influences the seismic properties differently compared to normal consolidation condition. The findings can be summarised as follows: 
1. Mineral composition and sorting have an effect on porosity and velocity both P- and S-waves mostly during the normal consolidation and less significantly during unloading and reloading.

2. Porosity and velocity deviate from the normal compaction trends during unloading and the degree of deviation increases with increasing preconsolidation stress.

3. Samples tested with different stress conditions (isotropic or uniaxial) applied to the sample show no significant difference in the measure properties during unloading.

4. Varying preconsolidation stress magnitudes do not significantly affect the change in porosity - velocities relation during unloading.

5. The total stress change during unloading caused the total porosity, P-and S-wave velocities to change by $5 \%, 25 \%$, and $50 \%$, respectively as a maximum, which constituted to the approximation of $\Delta \phi \sim \pm 5 \Delta \mathrm{V}_{\mathrm{P}}$ and $\Delta \mathrm{V}_{\mathrm{P}} \sim \pm 2 \Delta \mathrm{V}_{\mathrm{S}}$.

6. The partial velocity and porosity reversal seen during unloading reflects that only a minor part of the compaction is elastic.

7. Petrophysical well log data from the Barents Sea area show trends analogous to the data derived from the compaction experiments.

The experimental results presented herein are only valid for unconsolidated sands that have been compacted and unloaded/reloaded within the mechanical compaction domain. The results of the study and extensive dataset provided can be used in velocity modeling, timelapse seismic monitoring, basin analysis and potential seismic-geomechanics applications of shallow reservoir sands where mechanical compaction is the dominant process. Applications including rock physics modelling are reported in a companion paper. 


\section{ACKNOWLEDGEMENT}

We would like to thank the Norwegian Research Council (NFR) for funding the BarRock (Barents Sea Rock Properties) project under the program PETROMAKS (Programme for the Optimal Management of Petroleum Resources). We are also grateful to many NGI personnel especially Toralv Berre for their dedicated help with sample preparation, experimental setup and testing program. We thank Dave Dewhurst (CSIRO) for valuable input and discussion. We also thank the reviewers to improve readability of this paper.

\section{A LIST OF THE FIGURE LEGENDS}

Figure 1 Vertical cross-section of the triaxial setup used at NGI (after Berre 2011). The equipment and the setup are capable of measuring acoustic velocity and electrical conductivity in both vertical and horizontal directions. The changes in sample height and diameter were monitored by vertical and horizontal deformation sensors, respectively.

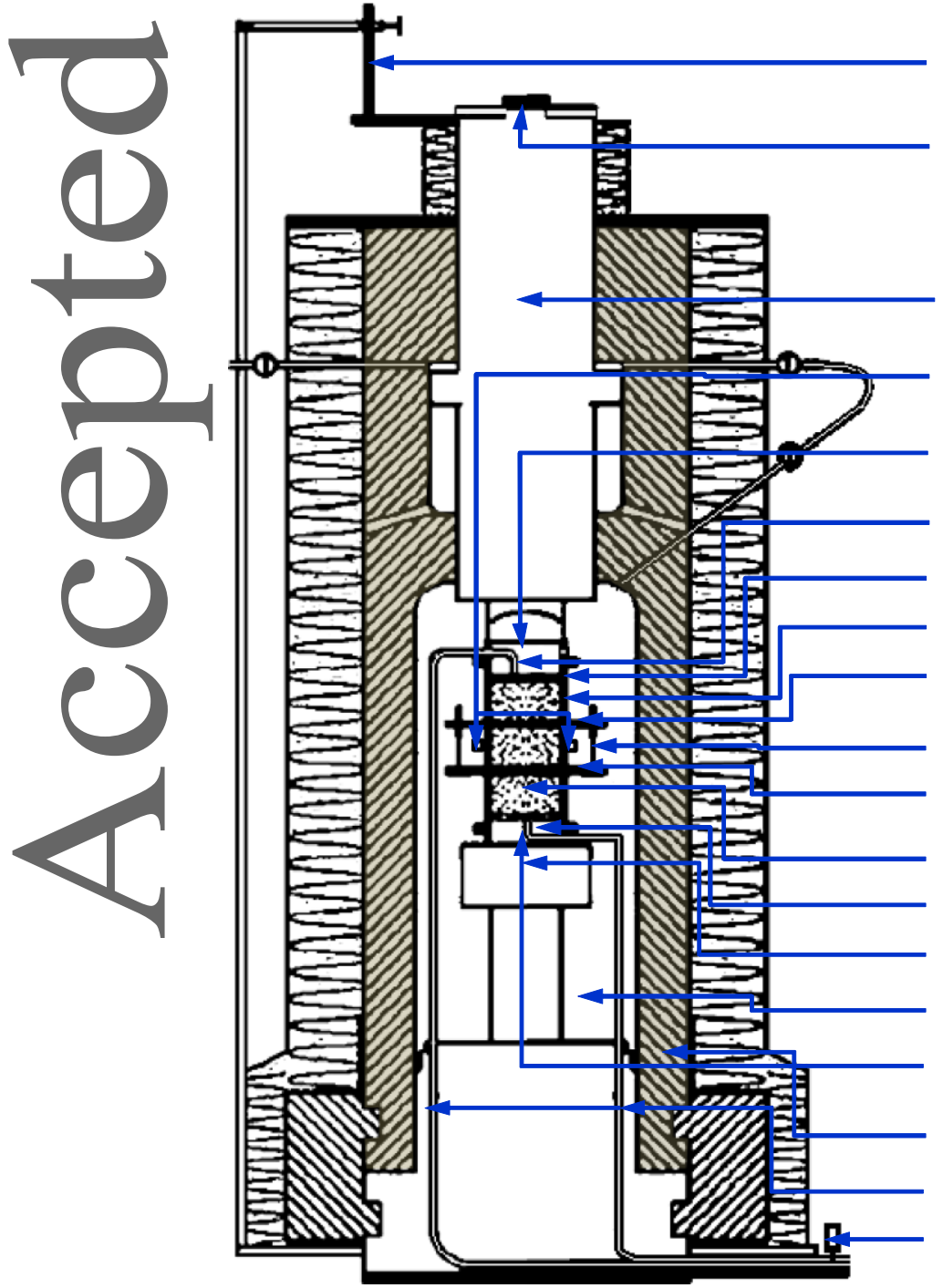

External vertical strain sensor Application of deviator load Piston (for application of deviator load) Horizonal acoustic/electric receiver/transmitter Vertical acoustic/electric transmitter Top cap Filter disk Rubber membrane Upper horizontal strain sensor Vertical strain sensor Lower horizontal strain sensor Rock specimen Pedestal Internal load cell Main pressure chamber (oil filled) Vertical acoustic/electric receiver Triaxial cell wall Drainage tubing Pore pressure sensor 
Figure 2 Loading protocol for experimental mechanical compaction applied to the sand samples in the present study. The procedure employs loading, unloading and reloading cycles. A step-by-step description is contained in Table 2. Unloading was applied at 15, 25, and $30 \mathrm{MPa}$ effective stresses before further reloading. The uniaxial strain loading $\left(\mathrm{K}_{0^{-}}\right.$ consolidation) condition is demonstrated in the upper left corner of the figure where zero horizontal strain, $\varepsilon_{\mathrm{h}}=0$, is controlled by adjustment of effective horizontal stress, $\sigma_{\mathrm{h}}$, while the effective vertical stress is increased, $\sigma^{\prime}{ }_{\mathrm{v}}$.
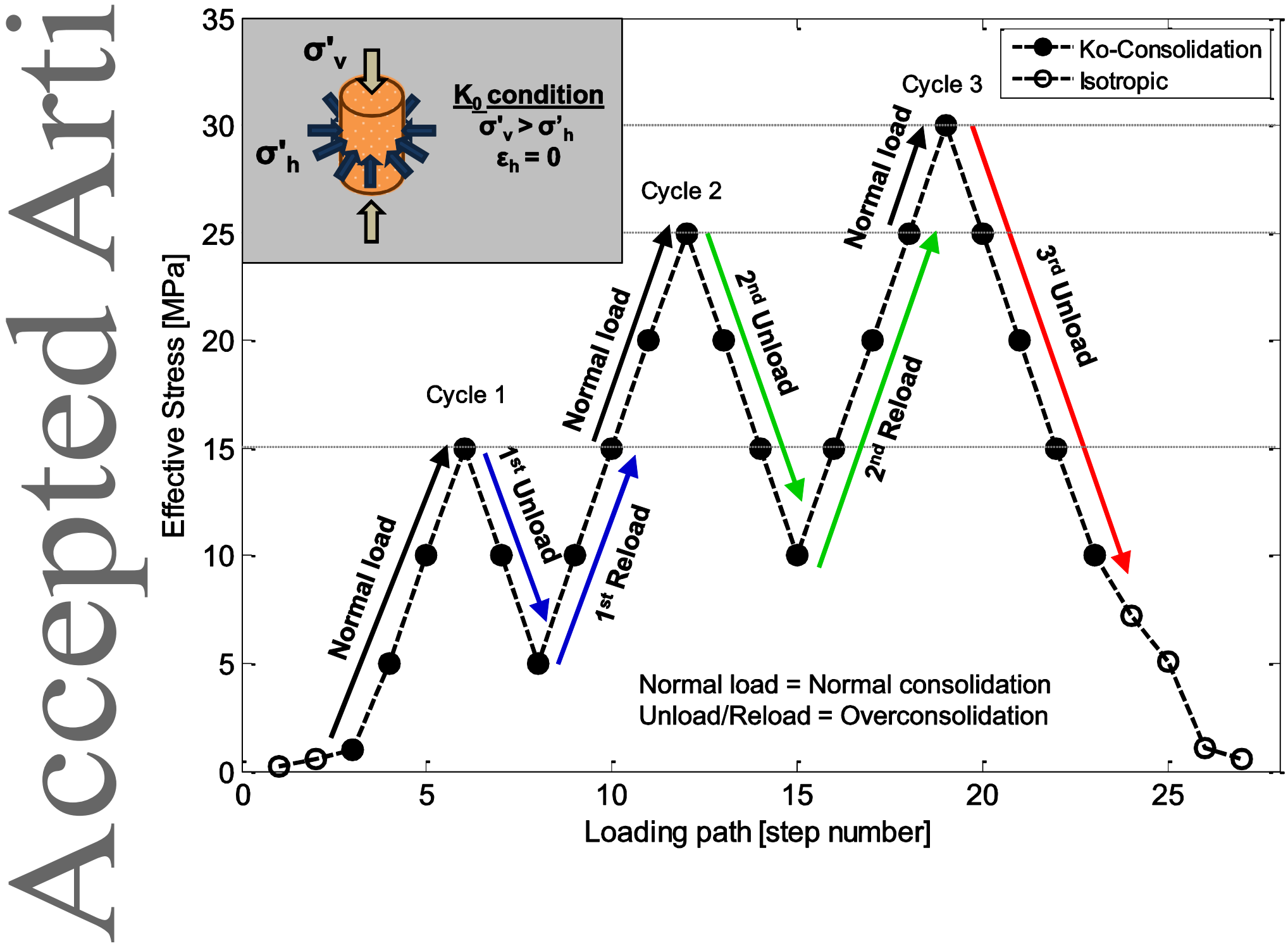

This article is protected by copyright. All rights reserved. 
Figure 3 Representative waveforms for P- and S-wave velocities. a) and c) are the reference signals taken from head-to-head configuration or no sample setup for P- and S- waves, respectively. b) and d) are $\mathrm{P}$-and $\mathrm{S}$-wave signals, respectively taken from one of the studied samples compacted to $15 \mathrm{MPa}$ effective stress. First arrival time picks are indicated by dotted lines. The travel time difference $\left(\Delta t_{P}\right.$ and $\left.\Delta t_{S}\right)$ between the reference signals and sample signals were calculated to estimate sample velocities.

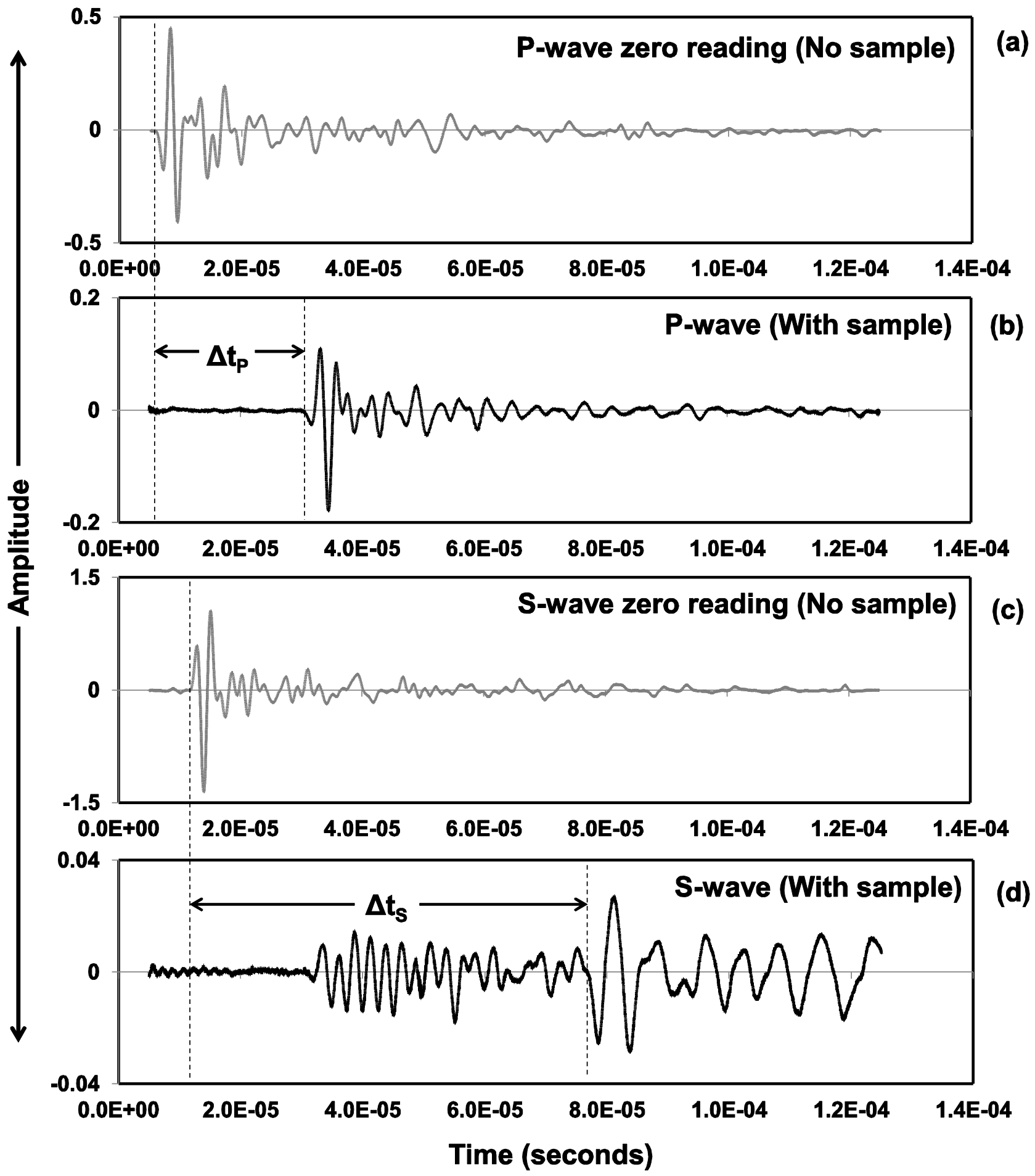


Figure 4 Example photographs of QA1 sands in different grain sizes ranging from $>1000 \mu \mathrm{m}$ (Very Coarse) to $<63 \mu \mathrm{m}$ (Silt) from sieve analysis

(1)
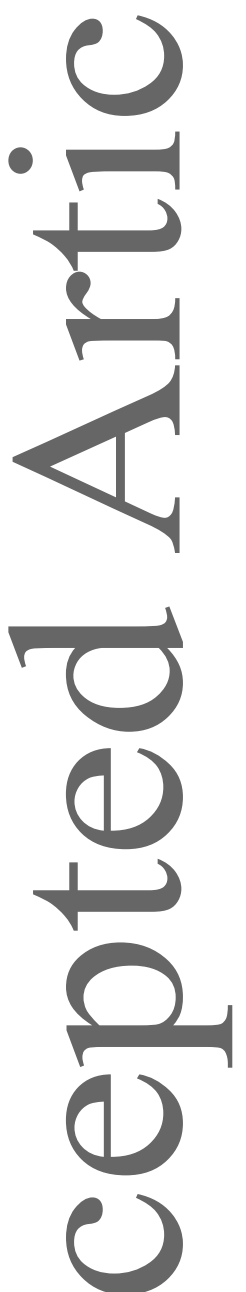

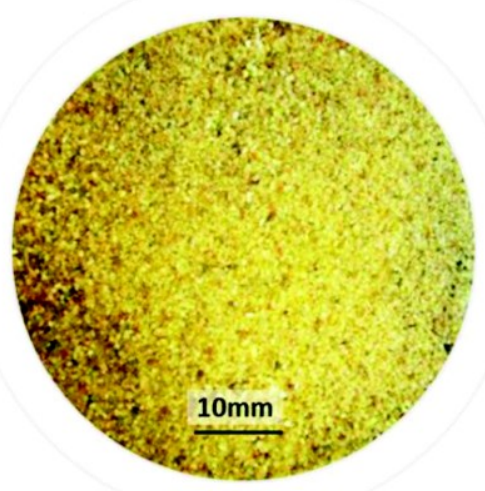

$500-1000 \mu \mathrm{m}$

Coarse

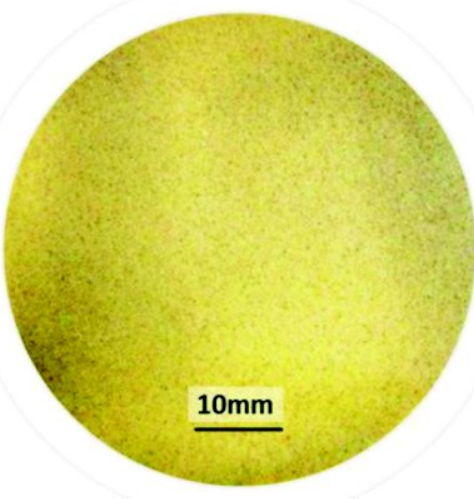

$63-125 \mu \mathrm{m}$

Very Fine

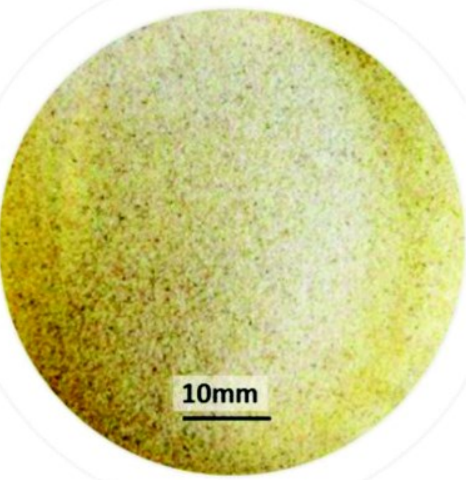

$250-500 \mu \mathrm{m}$

Medium

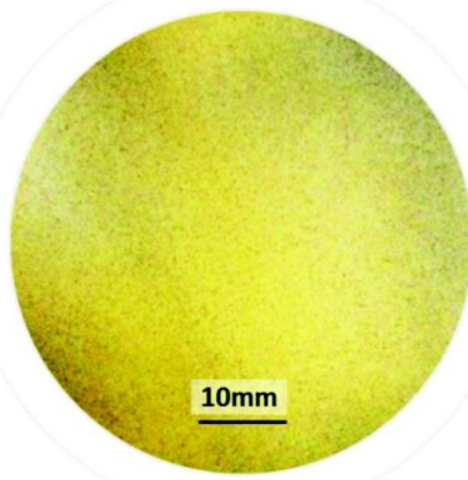

$<63 \mu \mathrm{m}$

Silt 
Figure 5 Total porosity, bulk density, and $\mathrm{P}$ and $\mathrm{S}$-wave velocities as functions of effective stress. Left column: the samples were grouped into $80-100 \%, 40-80 \%$, and $0-40 \%$ based on quartz percentage. Right column: the samples were grouped into poorly sorted, moderately sorted, and well sorted based on sorting classified using standard deviation of the grain size distribution. The plots show significant variations attributed to mineralogical compositions, sorting and stress path differences.
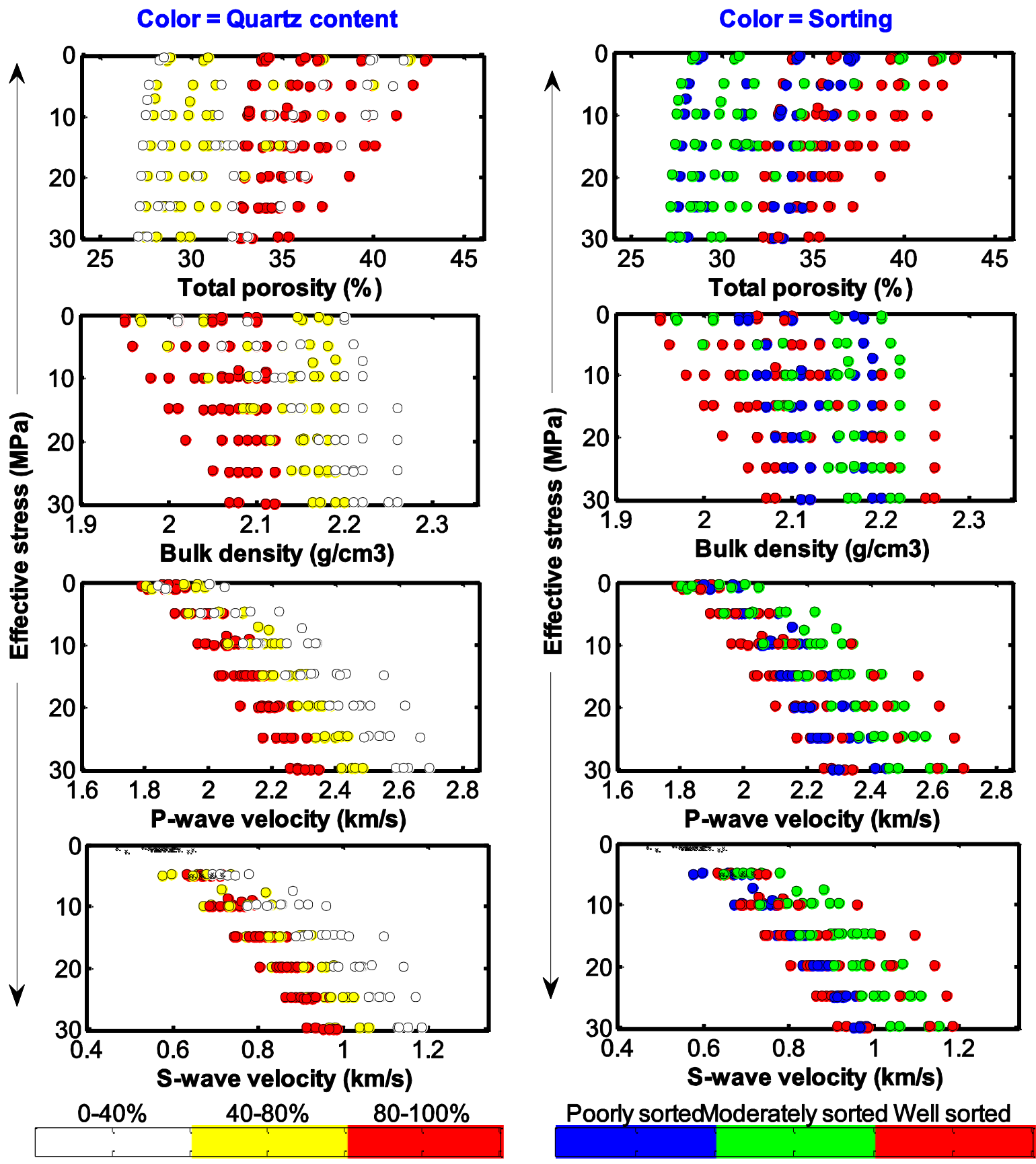

This article is protected by copyright. All rights reserved. 
Figure 6 Total porosity, and $\mathrm{P}$ and S-wave velocities as functions of effective stress. The first two columns: the samples were grouped into $0-40 \%, 40-80 \%$, and $80-100 \%$ based on quartz percentage. The last two columns: the samples were grouped into poorly sorted, moderately sorted, and well sorted based on sorting classified using standard deviation of the grain size distribution. The plots were separated between are normal loading (circles in column 1 and 3 ) and the last unloading step (rectangles in column 2 and 4). The plots show significant variations attributed to mineralogical compositions and sorting. Note that the effective stress is plotted in reverse.

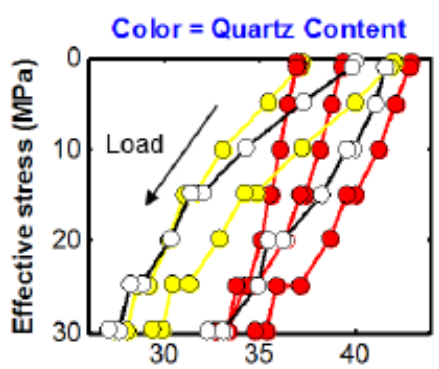

Total porosity $(\%)$
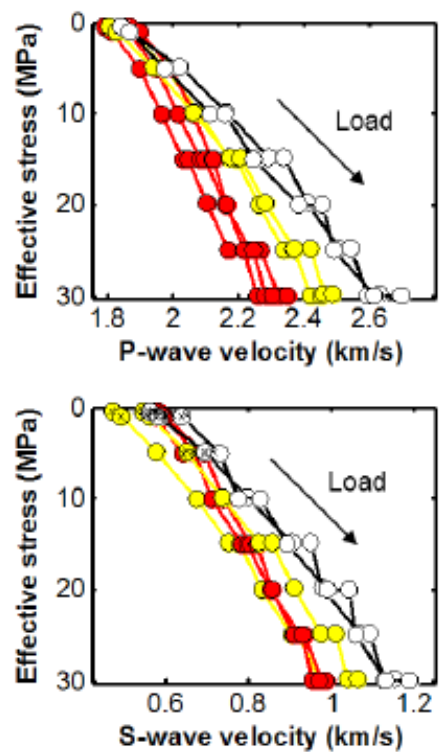

$0-40 \%$

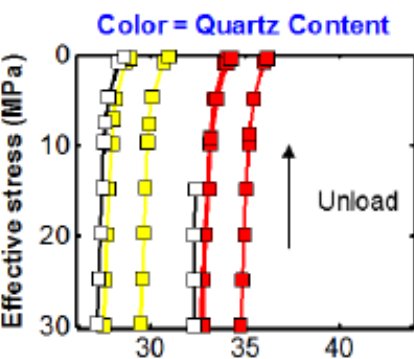

Total porosity $(\%)$
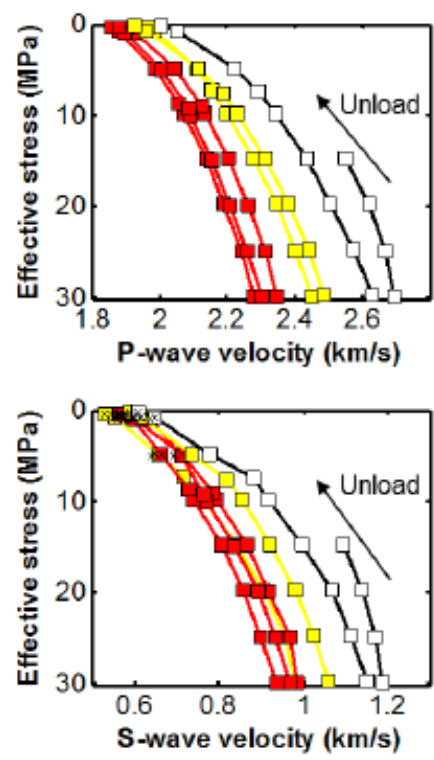

$80-100 \%$
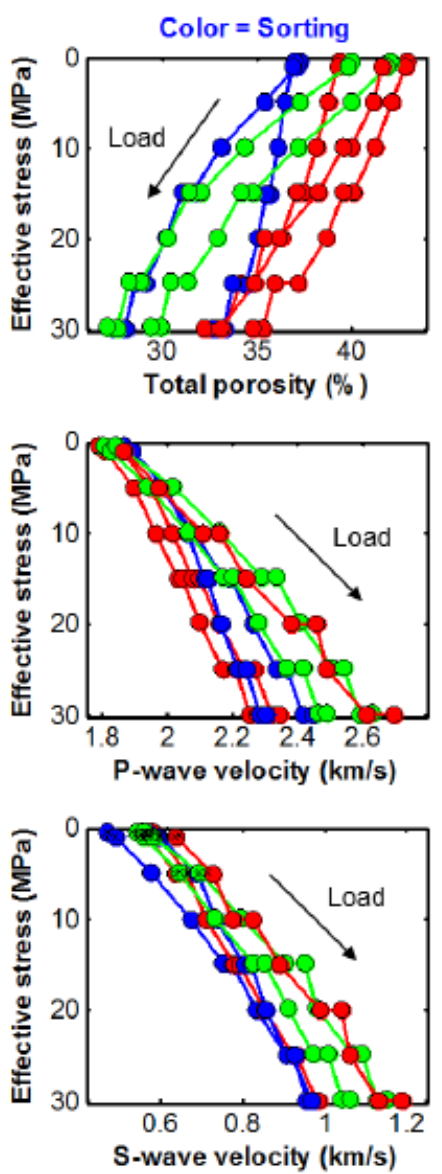

Poorly sorted

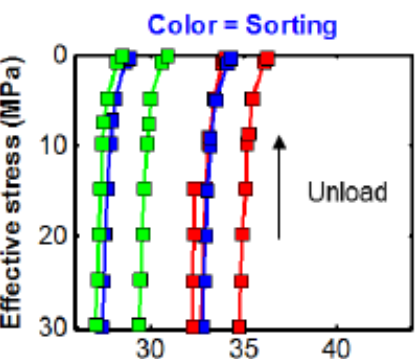

Total porosity $(\%)$
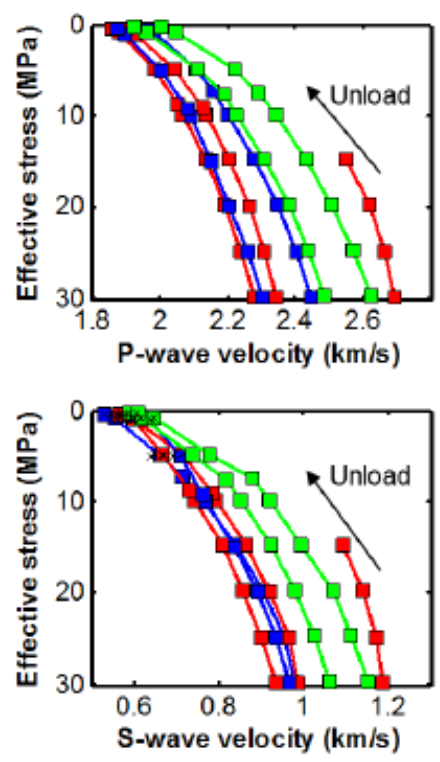

Moderately sorted

This article is protected by copyright. All rights reserved. 
Figure 7 Total porosity, and P- and S-wave velocities plotted as functions of effective stress for two representative sand samples, Quartz Arenite 2 (QA2) and Feldspatic Greywacke (FG). The selected samples are the two end members based on quartz volumetric content. Two separate trends distinguishing between normal consolidation (black curves with circles) and unloading/reloading (blue, green, and red curves with squares) can be observed for total porosity. The trends for velocities show only slight differences between normal consolidation and overconsolidation. The deviation of the unloading /reloading trends in all plots from the normal consolidated trends depends on the magnitude of the maximum preconsolidation stress prior to unloading. Red arrows show the direction of increase preconsolidation stress.
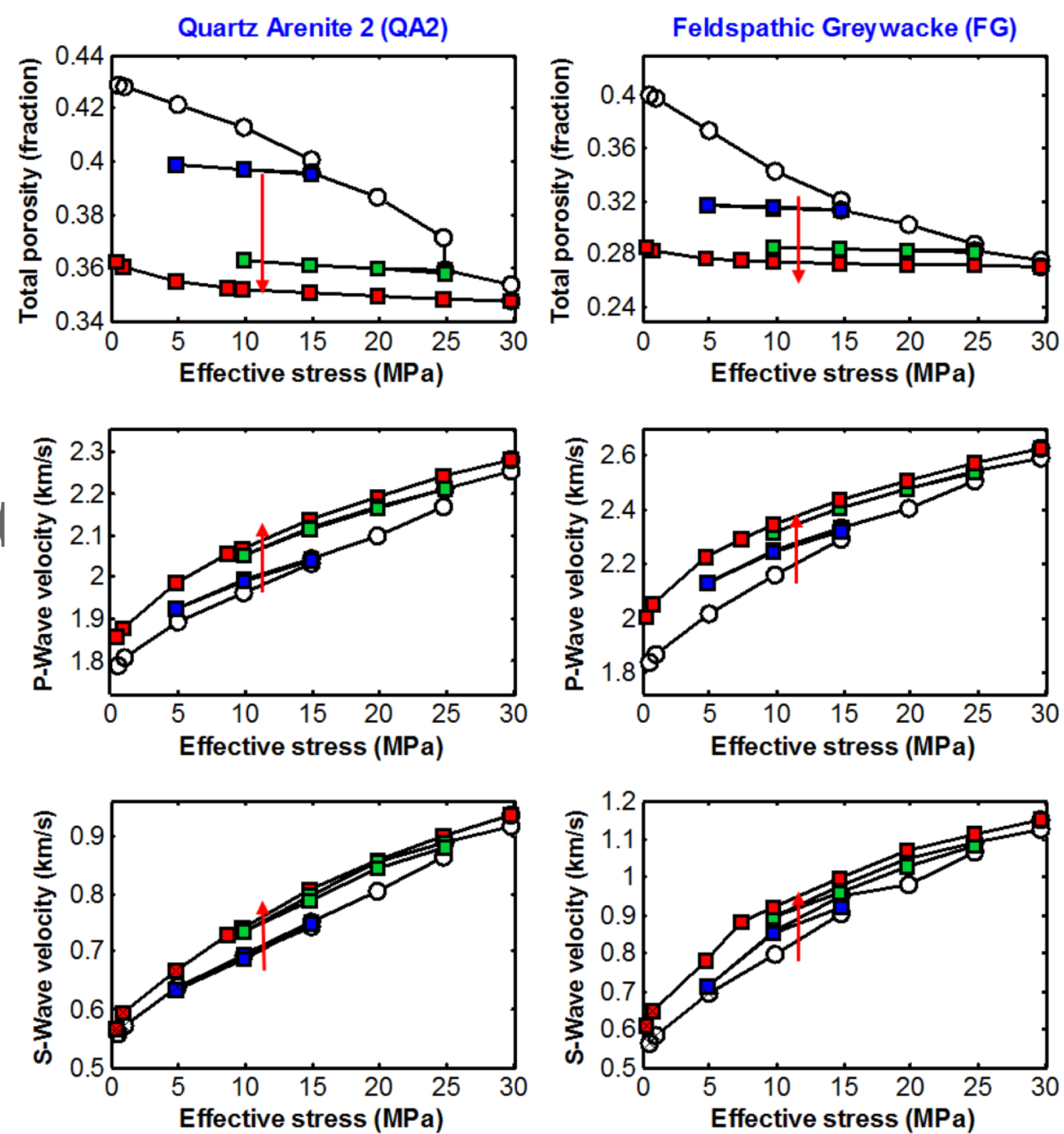

$\multimap-$ Normal consolidation $\rightarrow \square 1^{\text {st }}$ Unload/reload $\rightarrow \square-2^{\text {nd }}$ Unload/reload $\rightarrow \square 3^{\text {rd }}$ Unload 
Figure 8 P- and S-wave velocities versus total porosity of two end members, Quartz Arenite 2 (QA2, top) and Feldspathic Greywacke (FG, bottom). The colour coding reflects the effective stress at time of measurement. The plots demonstrated that the normal consolidation trends (black arrows) are much flatter than the trends observed during stress unloading/reloading (overconsolidation trends, red arrows) for both samples.

Data color $=$ Effective stress $(\mathrm{MPa})$
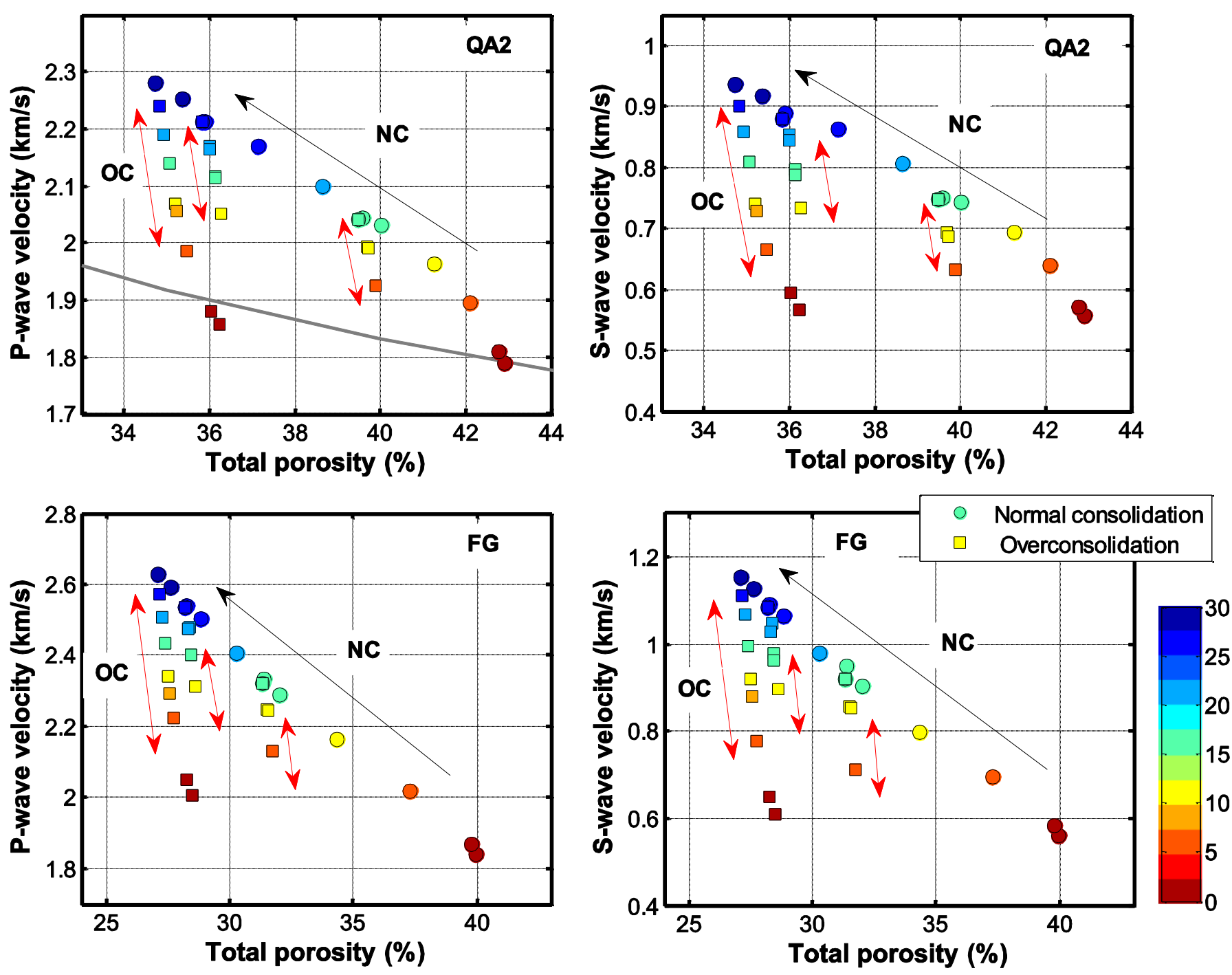
Figure 9 Effects of preconsolidation on the magnitude of changes in velocities ( $\mathrm{P}$ - and $\mathrm{S}$ waves) and total porosity during stress unloading/reloading for all samples, except VA. The variations in the symbols denote different samples. All the samples for all unloading pressure steps have the same magnitude of change after the stress was removed. (a) The effect of stress removal caused the P-wave velocity to decrease by $25 \%$ at the maximum when the effective stress was removed fully (100\%) from the previous maximum loading stage. (b) The velocity change in S-wave is higher, up to $50 \%$. (c) Total porosity in contrast was not affected by the release of stress significantly, only $5 \%$ changed is estimated due to the stress unloading effect. Polynomial best fit functions between the velocity change and the total porosity change were evaluated and are presented on the lower right plot (d).
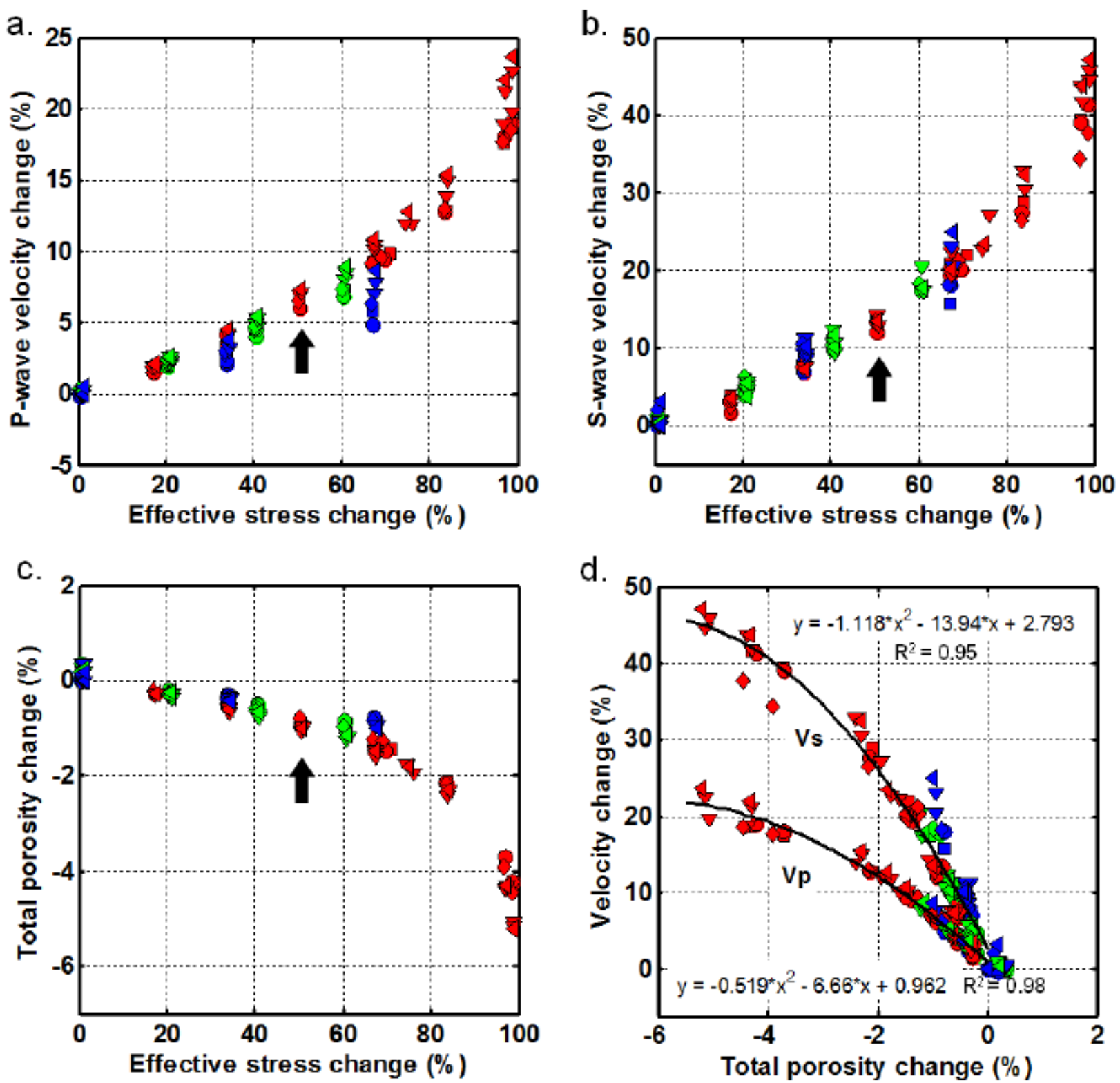

\section{- 1st Unload/Reload o 2nd Unload/Reload}

- 3rd Unload 
Figure 10 Comparisons between the present study and four previous published datasets. The plot shows P-and S-wave velocities versus total porosity data of the present study and the data from Yin (1992), Zimmer (2003), Fawad et al. (2011), and Zadeh et al. (2016). The samples used by Fawad et al. (2011) were the same as the present study. The plots show the same normal consolidation trend in all datasets (filled circles) for both P-and S-wave velocities. The overconsolidation trends derived from Zimmer (2003) data (open red squares) also shows a similar steep velocity-porosity gradient which correspond to what observed in the present study (open black squares).
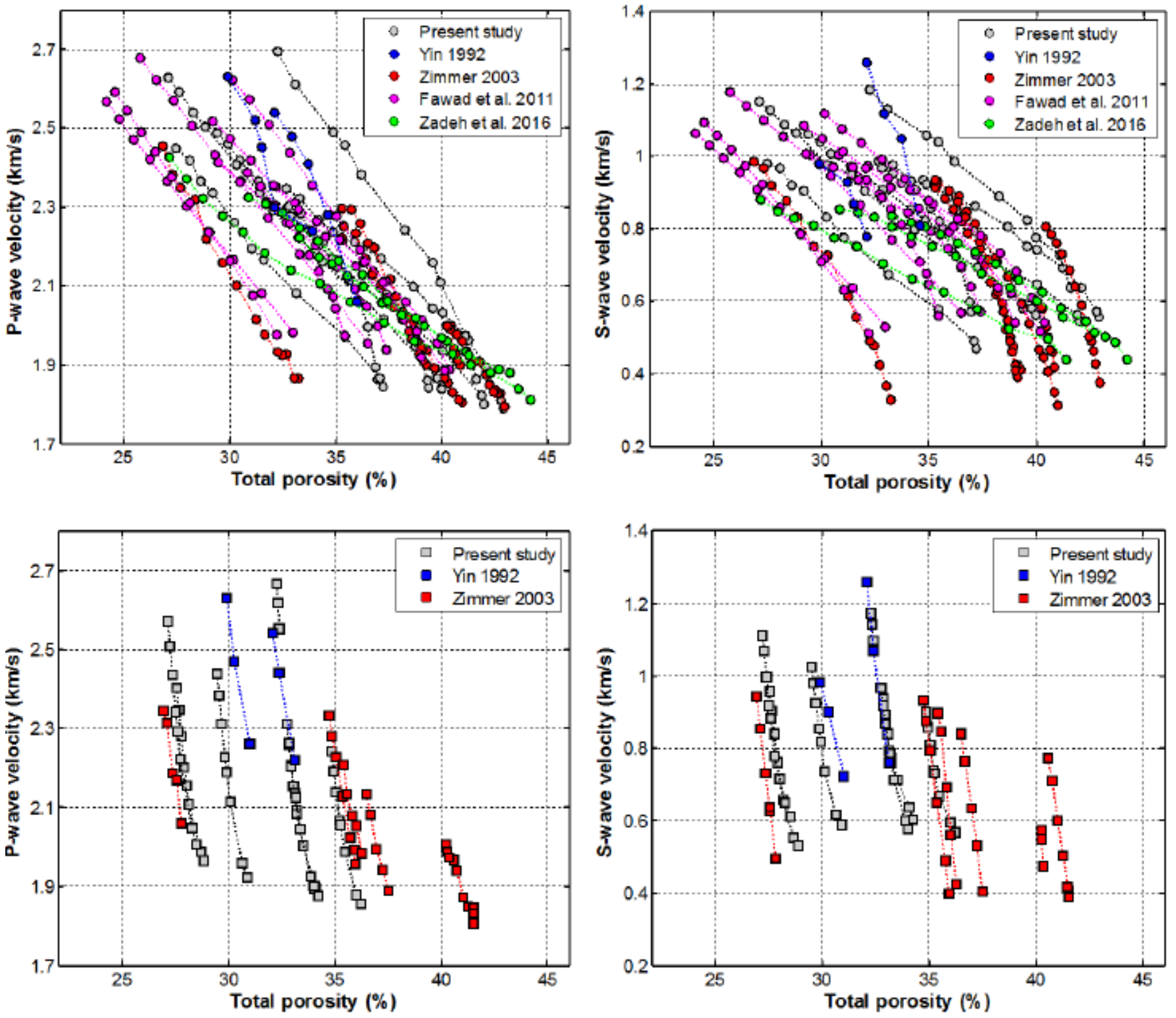

This article is protected by copyright. All rights reserved. 
Figure 11 Merrit sand samples from Zimmer (2003) are plotted for the percent changes in Pand S-wave velocities and total porosity on the final three unloading/reloading steps. The preconsolidation stress with the maximum stress varying at 10, 15, and $20 \mathrm{MPa}$ denote in blue, green, and red, respectively. The magnitude deviation from the start of the release of effective stress $\left(\Delta \sigma^{\prime} \mathrm{v}=0 \%\right)$ to highest degree of stress unloading $\left(\Delta \sigma^{\prime} \mathrm{v}=100 \%\right)$ accounts for $23 \%, 75 \%$, and $6 \%$ changes in $\mathrm{P}$ - wave, S-wave velocities and porosity, respectively. The changes have the same magnitude difference as observed in the present study, except for Swave velocities where the change in the Zimmer samples is higher.
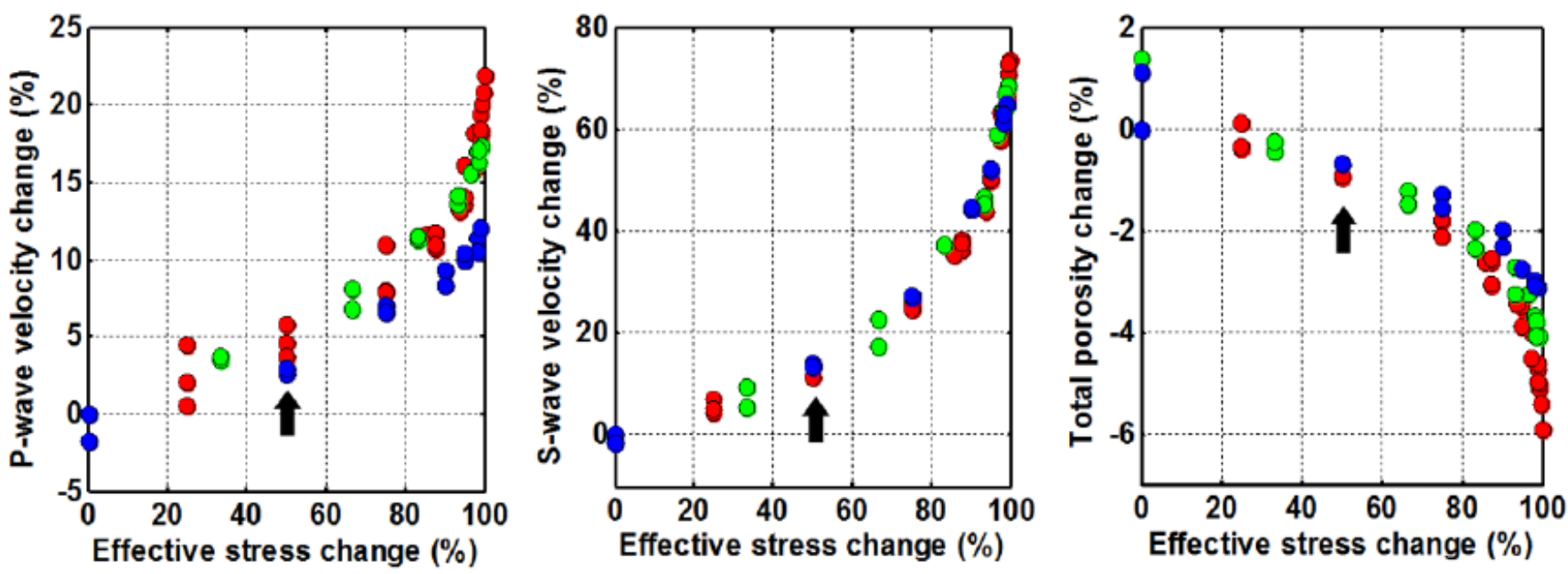

- 1st Unload/Reload $\quad$ 2nd Unload/Reload $\bullet$ 3rd Unload 
Figure 12 Comparison of sonic velocity (left) and bulk density (right) plotted as a function of depth in metres below sea floor between two Barents Sea wells (7117/9-1 and 7121/5-1). The 7117/9-1 well (black dots) has not been affected by uplift but the 7121/5-1 well has (red dots). The data represent Cenozoic sands from the Nordland Group and the Torsk Formation with $\mathrm{V}_{\text {clay }}<0.2$. The velocities and densities of the overconsolidated (uplifted) sands (red) are anomalously higher than the normally consolidated sands (black) found at the same present depth. High quartz samples from the experiments were superimposed on both plots for a comparison, where black and red dashed curves are the samples loaded under normal consolidation and unloading/reloading, respectively.
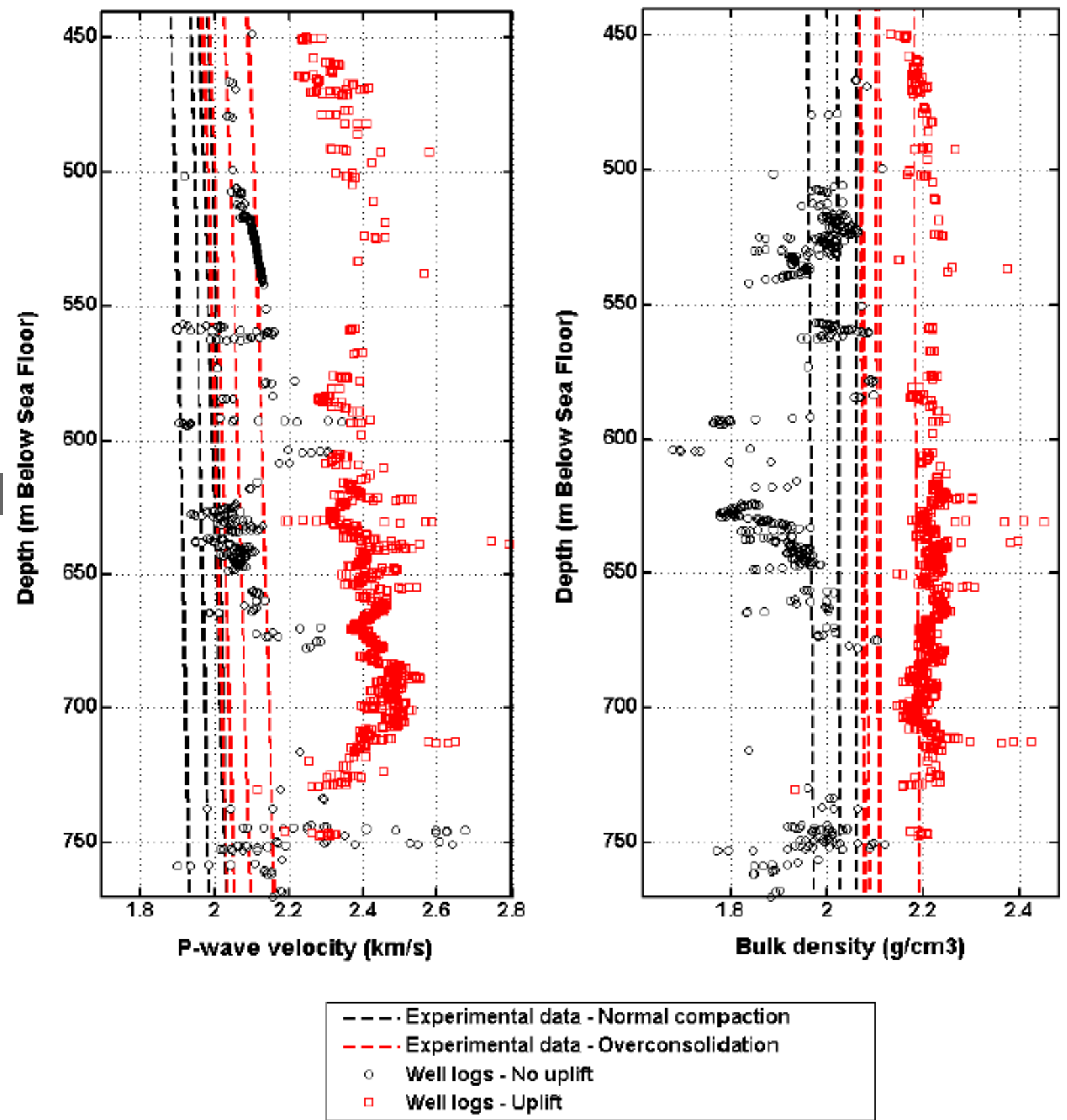

This article is protected by copyright. All rights reserved. 


\section{REFERENCES}

Al-Chalabi, M., and P. L. Rosenkranz, 2002, Velocity-depth and time-depth relationships for a decompacted uplifted unit: Geophysical Prospecting, 50, no. 6, 661-664

Avseth, P., T. Mukerji, and G. Mavko, 2005, Quantitative seismic interpretation: applying rock physics tools to reduce interpretation risk: Cambridge University Press

Avseth, P., and I. Lehocki, 2016, Combining burial history and rock-physics modeling to constrain AVO analysis during exploration, The Leading Edge, 35, no.6, 528-534

Berre, T., 2011, Triaxial testing of soft rocks: Geotechnical Testing Journal, 34, no. 1, 61-75.

Birch, F., 1960, The velocity of compressional waves in rocks to 10 kilobars, Journal of Geophysical Research, 65, 1083-1102

Bhuiyan, M. H. R. M. Holt, I. Larsen, and J. Stenebråten, 2013, Static and dynamic behaviour of compacted sand and clay: Comparison between measurements in Triaxial and Oedometric test systems, Geophysical Prospecting, 61, no. 2

Bjørlykke, K., 1999, Principal aspects of compaction and fluid flow in mudstones, In: Aplin, A.C., Fleet, A.J., Macquaker, J. H. S. (Eds.), Muds and Mudstones: Physical and Fluid Flow Properties, The Geological Society (London) Special Publications, No. 158, 73-78

Bjørlykke, K., 2010, Petroleum Geoscience. From Sedimentary Environments to Rock Physics, Springer, $508 \mathrm{p}$

Bjørlykke, K. and P. K. Egeberg, 1993, Quartz cementation in sedimentary basin, AAPG Bulletin, 77, 1536-1548

Brzesowsky, R. H., C. J. Spiers, C. J., Peach, and S. J. T. Hangx, 2014, Time-independent compaction behavior of quartz sands, Journal of Geophysical Research: Solid Earth, 119, 936-956

Bowers, G. L., 1995, Pore Pressure estimation from velocity data: Accounting for overpressure mechanisms besides undercompaction: Society of Petroleum Engineers, 10, no. 2, 89-95

Bowers, G.L., and T.J. Katsube, 2002, The role of shale pore-structure on the sensitivity of wireline logs to overpressure: in A.R. Huffman and G.L. Bowers, eds., Pressure regimes in sedimentary basins and their prediction, AAPG Memoir, 76, 43-60

Chuhan, F. A., A. Kjeldstad, K. Bjørlykke, and K. Høeg, 2003, Experimental compression of loose sands: relevance to porosity reduction during burial in sedimentary basins, Canadian Geotechnical Journal, 40, no. 5, 995-1011

Dewhurst, D. N., A. F. Siggins, J. Sarout, M. D. Raven, and H. M. Norgard-Bolas, 2011, Geomechanical and ultrasonic characterization of a Norwegian Sea shale, Geophysics, 76, no. $3,101-111$

Dvorkin, J., and A. Nur, 1996, Elasticity of high-porosity sandstones: theory for two North Sea datasets: Geophysics, 61, 1363-1370 
Dræge, A., K. Duffaut, T. Wiik, and K. Hokstad, 2014, Linking rock physics and basin history - Filling gaps between wells in frontier basins, The Leading Edge, 33, no. 3, 240246

Dott, R.H., 1964, Wacke, Greywacke and Matrix - What Approach to Immature Sandstone Classification?, Journal of Sedimentary Petrology, 34, 625-632

Faleide, J. I., A. Solheim, A. Fiedler, B. O. Hjelstuen, E. S. Andersen, and K. Vanneste, 1996, Late Cenozoic evolution of the western Barents Sea-Svalbard continental margin, Global and Planetary Change, 12, 53-74

Fawad, M., N. H. Mondol, J. Jahren, and K. Bjørlykke, 2011, Mechanical compaction and ultrasonic velocity of sands with different texture and mineralogical composition: Geophysical Prospecting, 59, no. 4, 697- 720

Gomez, C. T., J. Dvorkin., and T. Vanorio, 2010, Laboratory measurements of porosity, permeability, resistivity, and velocity on Fontainebleau sandstones, Geophysics, 75, no. 6, E191-E204

Goulty, N. R., 1998, Relationship between porosity and effective stress in shales, First Break, 16 , no. $12,413-419$

Grande, L., N. H. Mondol, and T. K. Berre, 2011, Horizontal stress development in finegrained sediments and mudstones during compaction and uplift, EAGE Extended Abstract, EarthDoc, P372, 73rd EAGE Conference \& Exhibition incorporating SPE EUROPEC, 23-26 May 2011, Vienna, Austria

Grude, S., M. Landrø, and B. Osdal, 2013, Time-lapse pressure-saturation discrimination for CO2 storage at the Snøhvit field, International Journal of Greenhouse Gas Controls, 19, 369378

Henriksen, E., Bjørnseth, H., Hals, T., Heide, T., Kiryukhina, T., Kløvjan, O., Larssen, G., Ryseth, A., Rønning, K., Sollid, K., 2011, Uplift and erosion of the greater Barents Sea: impact on

prospectivity and petroleum systems, Geological Society of London, Mem, 35, 271-281.

Holt, R. M., 1994, Effects of coring on petrophysical measurements, International Symposium of the Society of Core Analysts, paper SCA9407

Holt, R. M., 1999, Laboratory acoustic measurements for reservoir characterization: consequences of core alteration, International Symposium of the Society of Core Analysts, paper SCA9926

Hornby, B., 1998, Experimental laboratory determination of the dynamic elastic properties of wet, drained shales, Journal of Geophysical Research, 103, B12, 29945-29964

Japsen, P., P. F. Green, and J. A. Chalmers, 2005, Separation of Paleogene and Neogene uplift on Nuussuaq, West Greenland. Journal of the Geological Society, London, 162, 299314.

Jones L.E.A. and H. F. Wang, 1981, Ultrasonic velocities in Cretaceous shales from the Williston basin, Geophysics, 46, 288-297 
Ladd R S. ,1978, Preparing test specimens using undercompaction. Geotechnical Testing Journal, 1, no. 1, 16-23

Mondol, N. H., K. Bjørlykke, J. Jahren, and K. Hoeg, 2007, Experimental mechanical compaction of clay mineral aggregates - Changes in physical properties of mudstones during burial, Marine and Petroleum Geology, 24, no. 5, 289-311

Mondol, N. H., K. Bjørlykke, and J. Jahren, 2008, Experimental compaction of clays Relationship between permeability and petrophysical properties of mudstones, Petroleum Geoscience, v. 14, p. 319-337

Mondol, N. H., P. Avseth, M. Fawad, and T. Smith, 2010, Vs prediction in unconsolidated sands, Physical and Geological controls on shear wave velocity, 72nd EAGE Meeting, Expanded Abstract, p351.

Narongsirikul S., N. H. Mondol, and J. Jahren, 2013a, Possible application of friable sand model for shallow mechanically compacted overconsolidated sands, SEG International Exposition and 83th Annual Meeting, Houston, Texas, USA

Narongsirikul S., N. H. Mondol, and J. Jahren, 2013b, Acoustic, electric, and petrophysical properties of mechanically compacted sands of varying mineralogy - simulating the effects of uplift on rock properties. 2nd International Workshop on Rock Physics (2IWRP), Southampton, UK

Narongsirikul S., N. H. Mondol, and J. Jahren, 2013c, Density/porosity versus velocity of overconsolidated sands derived from experimental compaction. 75th EAGE Meeting, London

Narongsirikul S., N. H. Mondol, and J. Jahren, 2018, Acoustic, petrophysical and mechanical properties of mechanically compacted overconsolidated sands: Part 2 -Rock Physics Modelling and Applications, Geophysical Prospecting, v. 67, no. 1, 114 - 127

Nygård, R., M. Gutierrez, K. Høeg, and K. Bjørlykke, 2004, Influence of burial history on microstructure and compaction behavior of Kimmeridge clay, Petroleum Geoscience, 10, 259-270.

Ohm, S. E., Karlsen, D. A. \& Austin, T. J. F, 2008, Geochemically driven exploration models in uplifted areas: Examples from the Norwegian Barents Sea, AAPG Bulletin, 92, $1191-1223$

Pettersen, Ø., 2007, Sandstone Compaction, Grain Packing and Critical State Theory, Petroleum Geoscience, 13, 63-67

Prasad, M., 2002, Acoustic measurements in sands at low effective pressure: Overpressure detection in sands, Geophysics, v. 67, 2, $405-412$

Riis, F. and W. Fjeldskaar, 1992, On the magnitude of the Late Tertiary and Quaternary erosion and its significance for the uplift of Scandinavia and the Barents Sea. In: Larsen, R.M.,

Sarout, J. and L. Esteban, C. Delle Piane, B. Maney, D.N. Dewhurst, 2014, Elastic anisotropy of Opalinus Clay under variable saturation and triaxial stress. Geophysical Journal International, 198, 1662-1682 
Sarout, J. and Y. Le Gonidec, A. Ougier-Simonin, A. Schubnel, Y. Guéguen, and D.N. Dewhurst, 2017, Laboratory micro-seismic signature of shear faulting and fault slip in shale, Physics of the Earth and Planetary Interiors, 264, 47-62

Terzaghi, K., 1943, Theoretical soil mechanics, John Wiley \& Sons, Inc.

Tao, G., M. S. King, and M. Nabi-Bidhendi, 1995, Ultrasolic wave propagation in dry and brine-saturated sandstones as a function of effective stress: laboratory measurements and modelling, Geophysical Prospecting, 42, 299-328

Wang, Z., 2002a, Seismic anisotropy in sedimentary rocks, part 1: A single-plug method, Geophysics, 67, 1415-1422

Wang, Z., 2002b, Seismic anisotropy in sedimentary rocks, part 2: Laboratory data: Geophysics, 67, 1423-1440

Yin, H., 1992, Acoustic velocity and attenuation of rocks: Isotropy, intrinsic anisotropy and stress induced anisotropy. Ph. D. Thesis, Stanford University, CA, United States

Zadeh M. K., N. H. Mondol, J. Jahren, 2016, Experimental mechanical compaction of sands and sand-clay mixtures: a study to investigate evolution of rock properties with full control on mineralogy and rock texture, Geophysical Prospecting, 64, 915-941

Zimmer, M. A., 2003, Seismic velocities of unconsolidated sands: Measurements of pressure, sorting, and compaction effects, Ph.D. dissertation, Stanford University

Zimmer M. A., M. Prasad, G. Mavko, and A. Nur, 2007, Seismic velocities of unconsolidated sands: Part 1 - Pressure trends from 0.1 to $20 \mathrm{MPa}$, Geophysics, 72(1), E1-E13

Table 1 List of some important uplifted Petroleum provinces (modified from Henriksen et al. 2011)

\begin{tabular}{|l|l|l|l|}
\hline Basin & Country & Timing uplift & Nature of uplift \\
\hline San Juan & USA & Late Eocene-Recent & Epeirogenic-isostatic \\
\hline Permian & USA & Cretaceous-Recent & Epeirogenic-isostatic \\
\hline Maracaibo & Venezuela & Early Miocene- Late Eocene & Orogenic \\
\hline Zagros Foreland & Iran & Miocene-Recent & Orogenic \\
\hline Jungar & China & Miocene-Recent & Orogenic \\
\hline Western Canada & Canada & Oligocene-Recent & $\begin{array}{l}\text { Post Orogenic, } \\
\text { Epeirogenic-isostatic }\end{array}$ \\
\hline Timan Pechora & Russia & Miocene/Pliocene & Orogenic-isostatic \\
\hline Barents Sea & Norway & Palaeogene and Neogene & Orogenic-isostatic \\
\hline
\end{tabular}


Table 2 Description of loading procedures step-by-step.

\begin{tabular}{|ll|c|c|l|l|}
\hline Loading procedures & $\begin{array}{c}\text { Vertical eff. } \\
\text { stress (MPa) } \\
\text { From }\end{array}$ & $\begin{array}{c}\text { Vertical eff. } \\
\text { stress (MPa) } \\
\text { To }\end{array}$ & Cycle & Consolidation stage \\
\hline 1) & Isotropic stress condition & 0 & 0.52 & & Normal consolidation \\
\hline 2$)$ & $\mathrm{K}_{0}$ condition - Normal load & 0.52 & 15 & 1 & Normal consolidation \\
\hline 3$)$ & $\mathrm{K}_{0}$ condition $-1^{\text {st }}$ Unload & 15 & 5 & & Overconsolidation \\
\hline 4) $\quad \mathrm{K}_{0}$ condition $-1^{\text {st }}$ Reload & 5 & 15 & & Overconsolidation \\
\hline 5) & $\mathrm{K}_{0}$ condition - Normal load & 15 & 25 & 2 & Normal consolidation \\
\hline 6$) \quad \mathrm{K}_{0}$ condition $-2^{\text {nd }}$ Unload & 25 & 10 & & Overconsolidation \\
\hline 7$) \quad \mathrm{K}_{0}$ condition $-2^{\text {nd }}$ Reload & 10 & 25 & & Overconsolidation \\
\hline 8) & $\mathrm{K}_{0}$ condition - Normal load & 25 & 30 & 3 & Normal consolidation \\
\hline 9) & $\mathrm{K}_{0}$ condition $-3^{\text {rd }}$ Unload & 30 & 10 & & Overconsolidation \\
\hline 10) Isotropic stress condition & 10 & 0.55 & & Overconsolidation \\
\hline
\end{tabular}

Table 3 Mineral compositions and effective grain density of the sand samples from the XRD analysis (after Fawad et al. 2011)

\begin{tabular}{|c|c|c|c|c|c|}
\hline & \multicolumn{5}{|c|}{ Mineral constituents (weight percentage, \%) } \\
\hline Sample name & Quartz & Feldspar & Clay $^{2}$ & $\begin{array}{c}\text { Other } \\
\text { minerals }\end{array}$ & $\begin{array}{c}\text { Effective } \\
\text { grain } \\
\text { density } \\
\text { (g/cc) }\end{array}$ \\
\hline Quartz Arenite 1 (QA1) & 95.27 & 4.73 & - & - & 2.65 \\
\hline Quartz Arenite 2 (QA2) & 97.88 & 1.77 & - & 0.35 & 2.65 \\
\hline Sub Arkose 1 (SA1) & 91.27 & 8.73 & - & - & 2.65 \\
\hline Sub Arkose 2 (SA2) & 77.19 & 22.81 & - & - & 2.64 \\
\hline Arkosic Arenite (AA) & 54.84 & 34.18 & 10.97 & - & 2.65 \\
\hline Feldspathic Greywacke (FG) & 35.50 & 40.33 & - & 24.17 & 2.67 \\
\hline Volcanic Arenite (VA) & 4.84 & 52.51 & - & 42.65 & 2.81 \\
\hline
\end{tabular}

${ }^{1}$ Includes K-Feldspar, Albite, and Plagioclase

${ }^{2}$ Includes Kaolinite and Illite

${ }^{3}$ Mostly present in Volcanic Arenite including Aragonite, Calcite, Ankerite, Amphibole, and Augite

This article is protected by copyright. All rights reserved. 
Table 4 Textural variations of the sand samples (after Fawad et al. 2011)

\begin{tabular}{|c|c|c|c|c|c|c|c|c|c|}
\hline & & & \multicolumn{6}{|c|}{ Sand grain size distribution (weight percentage, \%) and sorting } \\
classification
\end{tabular}

Table 5 Previous published sand compaction data

\begin{tabular}{|c|c|c|c|c|c|c|c|c|}
\hline Source & Samples & $\begin{array}{l}\text { Main } \\
\text { Minerals }\end{array}$ & $\begin{array}{l}\text { Initial } \\
\text { Poros } \\
\text { ity } \\
(\%)\end{array}$ & $\begin{array}{l}\text { Test } \\
\text { equipment }\end{array}$ & $\begin{array}{l}\text { Stress } \\
\text { Conditions }\end{array}$ & $\begin{array}{l}\text { Maximu } \\
\text { m } \\
\text { Applied } \\
\text { stress } \\
\text { (MPa) }\end{array}$ & $\begin{array}{l}\text { Loading/Unl } \\
\text { oading } \\
\text { Procedures }\end{array}$ & Comment \\
\hline \multirow[t]{2}{*}{$\begin{array}{l}\text { Yin } \\
(1992)\end{array}$} & Ottawa Sands & Quartz & 36 & \multirow{2}{*}{$\begin{array}{l}\text { Hydrostatic } \\
\text { pressure } \\
\text { vessel } \\
\text { /Piezoelectr } \\
\text { ic } \\
\text { transducers }\end{array}$} & $\begin{array}{l}\text { Isotropic } \\
\text { loading }\end{array}$ & 50 & $\begin{array}{l}\text { Both } \\
\text { Loading \& } \\
\text { Unloading }\end{array}$ & - \\
\hline & $\begin{array}{l}95: 5 \text { Sand- } \\
\text { Clay }\end{array}$ & $\begin{array}{l}\text { Quartz } \\
\text { Kaolinite }\end{array}$ & 33.9 & & & & & - \\
\hline \multirow[t]{4}{*}{$\begin{array}{l}\text { Zimmer } \\
(2003)\end{array}$} & $\begin{array}{l}\text { Galveston } \\
\text { Sands }\end{array}$ & Quartz & 39.7 & \multirow{4}{*}{$\begin{array}{l}\text { Hydrostatic } \\
\text { pressure } \\
\text { vessel } \\
\text { /Piezoelectr } \\
\text { ic } \\
\text { transducers }\end{array}$} & $\begin{array}{l}\text { Isotropic } \\
\text { loading }\end{array}$ & 20 & $\begin{array}{l}\text { Both } \\
\text { Loading \& } \\
\text { Unloading }\end{array}$ & - \\
\hline & $\begin{array}{l}\text { Gulf of } \\
\text { Mexico Sands }\end{array}$ & $\begin{array}{l}\text { Quartz } \\
\text { Plagiocla } \\
\text { se }\end{array}$ & 42.7 & & & & & - \\
\hline & Merrit Sands & $\begin{array}{l}\text { Quartz } \\
\text { K- } \\
\text { Fledspar }\end{array}$ & 33.9 & & & & & - \\
\hline & $\begin{array}{l}\text { Pomponio } \\
\text { Sands }\end{array}$ & $\begin{array}{l}\text { Quartz } \\
\text { Plagiocla }\end{array}$ & 43.5 & & & & & - \\
\hline
\end{tabular}

This article is protected by copyright. All rights reserved. 


\begin{tabular}{|c|c|c|c|c|c|c|c|c|}
\hline & & $\mathrm{se}$ & & & & & & \\
\hline & $\begin{array}{l}\text { Santacruz } \\
\text { Sands } 1\end{array}$ & $\begin{array}{l}\text { Quartz } \\
\text { Plagiocla } \\
\text { se }\end{array}$ & 40 & & & & & - \\
\hline & $\begin{array}{l}\text { Santacruz } \\
\text { Sands } 2\end{array}$ & $\begin{array}{l}\text { Quartz } \\
\text { Plagiocla } \\
\text { se }\end{array}$ & 41.7 & & & 2.3 & & $\begin{array}{l}\text { Load up to } \\
\text { only } 2.3 \\
\mathrm{MPa} \\
\text { pressure }\end{array}$ \\
\hline \multirow[t]{7}{*}{$\begin{array}{l}\text { Fawad } \\
\text { et al. } \\
(2011) \\
\end{array}$} & QA2 & Quartz & 36 & Oedometer & $\begin{array}{l}\text { Uniaxial } \\
\text { loading }\end{array}$ & 50 & Loading only & - \\
\hline & QA1 & Quartz & 41 & & & & & - \\
\hline & SA1 & $\begin{array}{l}\text { Quartz } \\
\text { Feldspar }\end{array}$ & 38 & & & & & - \\
\hline & SA2 & $\begin{array}{l}\text { Quartz } \\
\text { Feldspar }\end{array}$ & 34 & & & & & - \\
\hline & $\overline{\mathrm{AA}}$ & $\begin{array}{l}\text { Quartz } \\
\text { Albite }\end{array}$ & 42 & & & & & - \\
\hline & FG & $\begin{array}{l}\text { Quartz } \\
\text { Feldspar }\end{array}$ & 39 & & & & & - \\
\hline & $\overline{\mathrm{VA}}$ & $\begin{array}{l}\text { Plagiocla } \\
\text { se } \\
\text { Augite }\end{array}$ & 40 & & & & & - \\
\hline \multirow{3}{*}{$\begin{array}{l}\text { Zadeh } \\
\text { et al. } \\
\text { (2016) }\end{array}$} & Sand & Quartz & 44 & Oedometer & $\begin{array}{l}\text { Uniaxial } \\
\text { loading }\end{array}$ & 30 & Loading only & - \\
\hline & $\begin{array}{l}\text { 90:10 Sand- } \\
\text { Kaolinite }\end{array}$ & $\begin{array}{l}\text { Quartz } \\
\text { Kaolinite }\end{array}$ & 43 & & & & & - \\
\hline & $\begin{array}{l}80: 20 \text { Sand- } \\
\text { Kaolinite }\end{array}$ & $\begin{array}{l}\text { Quartz } \\
\text { Kaolinite }\end{array}$ & 43 & & & & & - \\
\hline
\end{tabular}

